\title{
mRNA Polyplexes with Post-Conjugated GALA Peptides Efficiently Target, Transfect, and Activate Antigen Presenting Cells
}

\author{
Bo Lou, ${ }^{\dagger}$ Stefaan De Koker, ${ }^{\S}$ Chun Yin Jerry Lau, ${ }^{\dagger}$ Wim E. Hennink, ${ }^{\dagger}{ }^{\circ}$ and Enrico Mastrobattista ${ }^{*}{ }^{\dagger}$
}

${ }^{\dagger}$ Department of Pharmaceutics, Utrecht Institute for Pharmaceutical Sciences (UIPS), Utrecht University, 3584CG Utrecht, The Netherlands

${ }^{\S}$ Laboratory of Molecular Immunology, Department of Biomedical Molecular Biology, Ghent University, 9052 Zwijnaarde, Belgium

Supporting Information

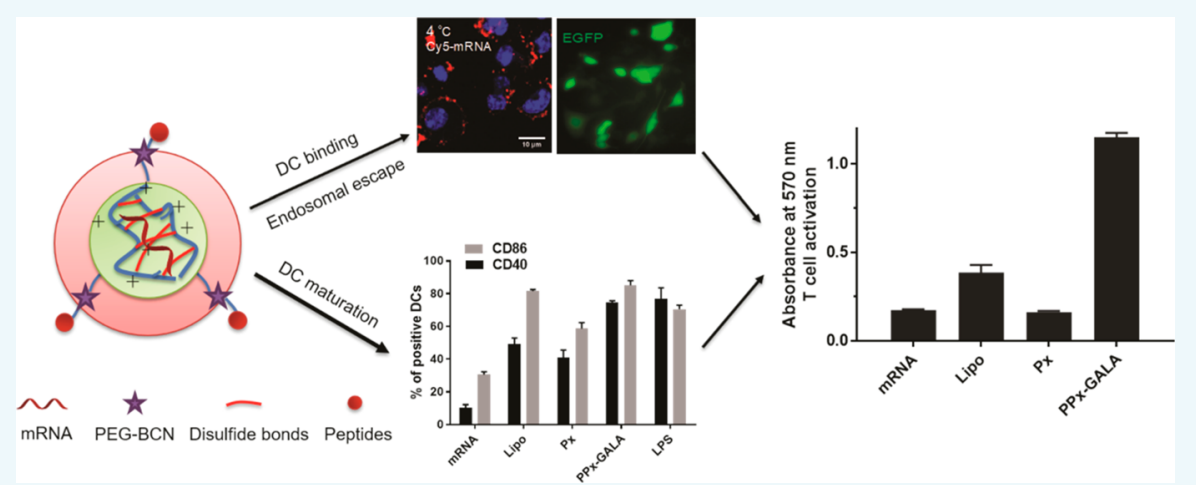

ABSTRACT: Vaccines based on mRNA have emerged as potent systems to elicit $\mathrm{CD}^{+} \mathrm{T}$ cell responses against various cancers and viral infectious diseases. The efficient intracellular delivery of mRNA molecules encoding antigens into the cytosol of antigen-presenting cells (APCs) is still challenging, requiring cell attachment, active uptake, and subsequent endosomal escape. Here, we report a facile approach for the formulation of peptide-functionalized mRNA polyplexes using copper-free click chemistry to promote presentation of mRNA antigen by dendritic cells (DCs). After screening different membrane active peptides, GALA modified mRNA polyplexes (PPx-GALA) with a size around $350 \mathrm{~nm}$ and with a slightly negative surface charge $(-7 \mathrm{mV})$, exhibited the highest EGFP-mRNA transfection in RAW 246.7 macrophages $(\sim 36 \%)$ and D1 dendritic cells $(\sim 50 \%)$ as compared to polyplexes decorated with melittin or LEDE peptides. Interestingly, we found that PPx-GALA enters DCs through sialic acid mediated endo/phagocytosis, which was not influenced by DC maturation. The PPx-GALA formulation exhibited 18-fold higher cellular uptake compared to a lipofectamine mRNA formulation without inducing cytotoxicity. Live cell imaging showed that PPx-GALA that were taken up by endocytosis induced calcein release from endosomes into the cytosol. DCs treated with PPx-GALA containing mRNA encoding for OVA displayed enhanced T cell responses and DC maturation. Collectively, these data provide a strong rationale for further study of this PPx-GALA formulation in vivo as a promising mRNA vaccine platform.

\section{INTRODUCTION}

The induction of robust antigen-specific $\mathrm{T}$ cell responses is a necessity for effective immunotherapy of cancer and for the treatment of persistent viral infections. ${ }^{1}$ Recent clinical successes on chimeric antigen receptor $\mathrm{T}$ cell (CAR $\mathrm{T}$ cell) therapies in blood cancers have led to the approval of two CAR-T cell therapies by the Food and Drug Administration (FDA) in $2017 .^{2}$ While exciting, these engineered CAR $T$ cell therapies so far have limited efficacy for solid tumors and are costly for widespread application and are thus less suitable to be used for treating infectious diseases. ${ }^{3}$ An alternative and traditional way to activate antigen-specific $\mathrm{T}$ cell responses is to use dendritic cells (DCs)-based vaccines. ${ }^{4}$ DCs, as potent antigen presenting cells (APCs), play a crucial role in the initiation and regulation of adaptive immune responses and are the key orchestrators of $\mathrm{T}$ cell responses. For efficient induction of cytolytic $\mathrm{T}$ cell responses, the antigen needs to be delivered into the cytosol of DCs and, after processing, incorporated into the major histocompatibility complex (MHC) class I molecules for presentation on the cell surface and potential recognition by CD8+ T lymphocytes. Nucleotide vaccines, especially mRNA vaccines, are very attractive, since they exhibit the ability to induce a strong CD8+ $\mathrm{T}$ cell response without the potential danger of genome integration from DNA vaccines or the limitation of antigen selection from peptide vaccines. ${ }^{5,6}$ However, the lack of efficient delivery

Special Issue: Delivery of Proteins and Nucleic Acids: Achievements and Challenges

Received: July 24, 2018

Revised: September 5, 2018

Published: September 6, 2018 


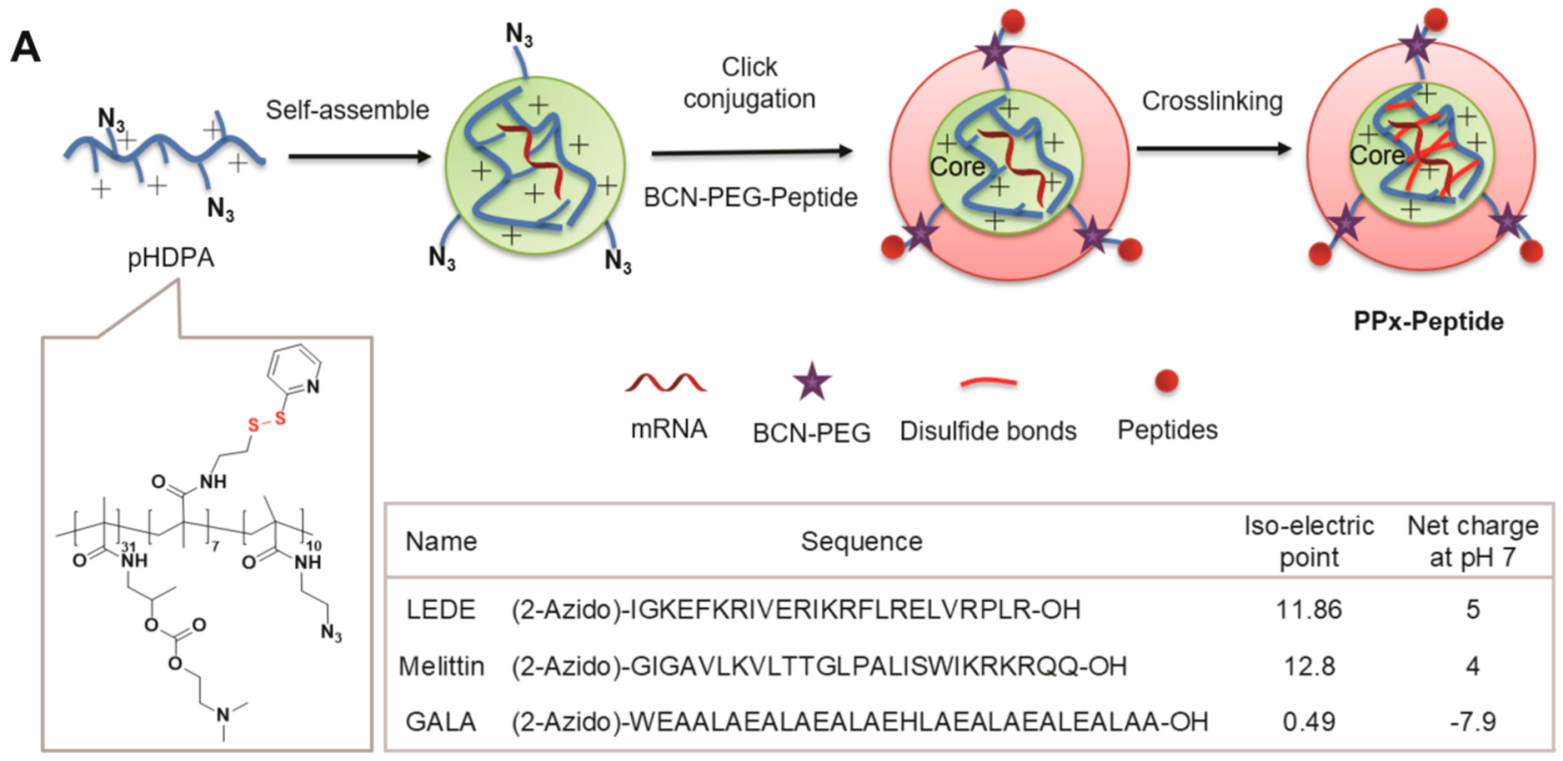

Nomenclature:

BCN-PEG modified mRNA polyplexes $=\mathbf{P x}$

BCN-PEG-peptide modified mRNA polyplexes = PPx, e.g. PPx-LEDE, PPx-Melittin and PPx-GALA

B

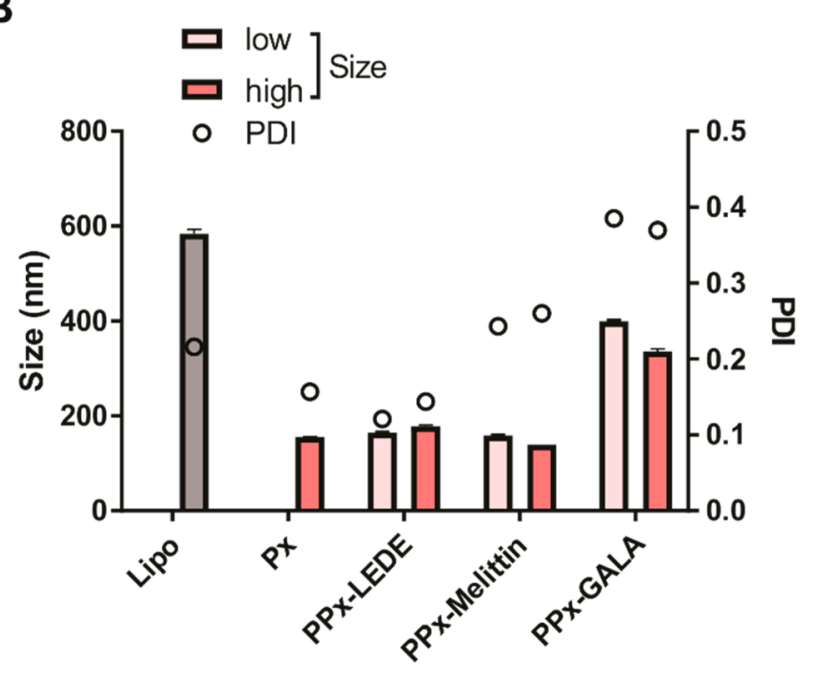

C

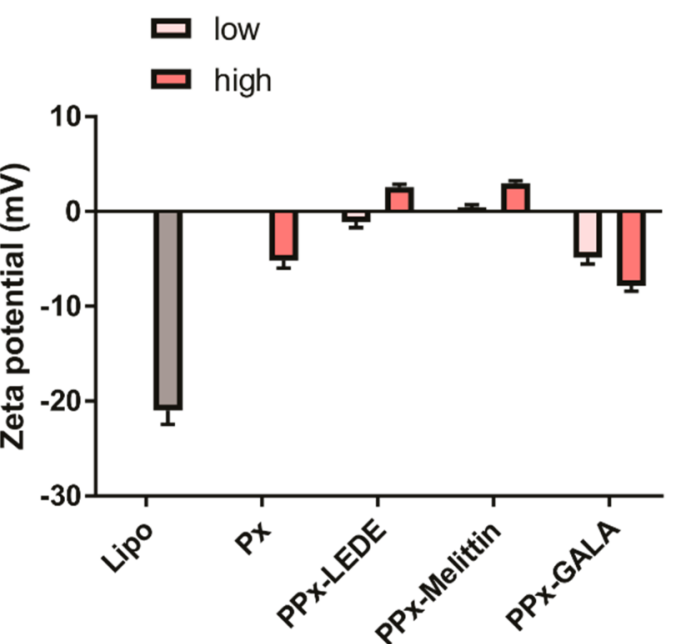

Figure 1. Preparation and characterization of peptide-modified mRNA polyplexes (PPx). (A) Schematic illustration of the 3-step preparation method of PPx: (a) core self-assembly by mixing the cationic polymer and mRNA; (b) low or high degree of PEG-BCN ${ }_{6000}$-peptide is conjugated to the $\mathrm{pHDPA} / \mathrm{mRNA}$ polyplexes by click chemistry; and (c) particle stabilization by cross-linking the polymer chains of the core with DTT. (B) Particle size, polydispersity index (PDI) and zeta potential (C) of peptide modified EGFP mRNA PPx at low or high amount of peptide surface modification. mRNA polyplexes were diluted to $10 \mu \mathrm{g} / \mathrm{mL}$ in $10 \mathrm{mM}$ HEPES buffer $\mathrm{pH}$ 7.4. Lipo represents mRNA formulated with Lipofectamine 2000 at weight/volume ratio of $1 / 1.5$ into lipoplexes. Data are the mean $\pm \mathrm{SD}, n=3$.

systems for transfection of APCs remains a major hurdle in the development of mRNA-based vaccines. The main challenges for nonviral mRNA vaccine delivery include therefore (1) selectively delivering mRNA to antigen presenting cells, most preferentially DCs inside the lymph nodes, (2) triggering efficient cellular uptake and endosomal escape to release mRNA into the cytosol, and (3) circumventing the detrimental impact of type I interferon (IFN) secretion triggered by exogenous mRNA uptake. ${ }^{7,8}$

Various delivery systems originally developed for cellular transfection with DNA and small interfering RNAs (siRNA) have been employed as mRNA delivery agents. ${ }^{9}$ Among them, the most studied and promising are lipoplexes (i.e., mRNA complexed with cationic lipids) or lipid nanoparticles (i.e., solid or vesicular nanoparticles with an outer lipid bilayer structure) based on synthetic/natural lipids. ${ }^{10-12}$ Lipid-based delivery systems have shown good transfection levels with APCs both in vitro and in vivo; however, the maturation of DCs induced by the self-adjuvanting effect of mRNA via Toll like receptor (TLR7/8) activation hampers further RNA internalization due to abrogated macropinocytosis, which is the predominant DC cellular uptake pathway of lipid-based mRNA particles. $^{13,14}$ This drawback can be overcome by using mRNA containing modified nucleosides to diminish the DC maturation. However, additional TLR agonists were then required to exploit the full potential of the mRNA vaccine. ${ }^{15}$ Cationic polymers as an alternative, such as polyethylenimine (PEI), poly(L-lysine) (PLL), poly(dimethylaminoethyl meth- 
acrylate) (pDMAEMA), and polyaspartamides (PAsp(DET)), have been studied over the past decades to deliver pDNA and siRNA. ${ }^{8,16}$ Despite the fact that these polymers have shown successful delivery of mRNA into tumor cells with acceptable levels of protein expression, only a few studies have been reported to effectively transfect APCs. ${ }^{17-19}$ Several novel cationic polymers and peptides have been shown to deliver mRNA into APCs in vitro with efficiencies of $20-80 \%$ of transfected cells. ${ }^{20-23}$ Although promising for in vitro applications, due to their highly positive surface charge they are less suitable for direct in vivo application.

Previously, we developed single-stranded poly uridine (PolyU) polyplexes that were post-modified with PEG as a novel particulate RNA adjuvant. These PEGylated RNA polyplexes ( $\mathrm{Px}$ ) exhibited superior targeting ability to DCs in the lymph nodes, and successfully elicited strong $\mathrm{CD}^{+}$ cytolytic $\mathrm{T}$ cell responses when coadministered with OVA via the subcutaneous route. ${ }^{24}$

In present study, the aim was to further employ this delivery system as mRNA vaccine platform and to obtain efficient endosomal escape of antigen-encoding mRNA by postfunctionalizing the RNA polyplexes with different membraneactive peptides at the distal end of the surface-exposed PEG chains. These peptides included the cationic and hemolytic peptide melittin, ${ }^{25,26}$ a $\mathrm{pH}$-sensitive fusogenic peptide GALA $^{27,28}$ and an antimicrobial peptide LEDE ${ }^{29-31}$ (sequence see Figure 1, gift from Dr. Drijfhout, Leiden University Medical Center). Preliminary experiments showed that the LEDE peptide has mild membrane leakage properties and that LEDEfunctionalized Luc-mRNA polyplexes (PPx-LEDE) showed 100 times increase in luciferase expression in mouse fibroblast NIH3T3 cells compared to PEGylated mRNA polyplexes without the peptide (Px) (Figure S2). All three peptides were post-conjugated to the mRNA polyplexes and screened for mRNA transfection in different antigen presenting cells. Our data revealed that GALA-modified mRNA polyplexes (PPxGALA) efficiently transfected macrophages and DCs with EGFP mRNA to a comparable or higher transfection level as compared to formulation of mRNA with the commercial lipofectamine and without any noticeable cytotoxicity. We further investigated the cellular uptake mechanism and intracellular trafficking process of PPx-GALA in DCs and found that the GALA peptides serve a dual function: they selectively bind to sialic acid terminated glycans on DCs leading to internalization and subsequent cytosolic release, presumably by facilitating endo/phagosome membrane disruption. Moreover, delivery of OVA mRNA with these GALAfunctionalized polyplexes resulted in efficient transfection and activation of DCs, thereby promoted strong OVA-specific $\mathrm{T}$ cell activation in vitro.

\section{RESULTS AND DISCUSSION}

Preparation and Characterization of Peptide Modified mRNA Polyplexes. In this study, a random copolymer $\mathrm{p}$ (HPMA-DMAE-co-PDTEMA-co-AzEMAm) (pHDPA) containing azide functional groups was synthesized (Figure $1 \mathrm{~A}$ and S1, $M_{\mathrm{n}}=11.2 \mathrm{kDa}$ (PEG calibration), $M_{\mathrm{w}} / M_{\mathrm{n}}=1.9$ ).

Peptide modified mRNA polyplexes (PPx) were prepared in three steps as illustrated in Figure 1A. mRNA was first complexed with pHDPA via electrostatic interactions with an amine to phosphate $(\mathrm{N} / \mathrm{P})$ molar ratio of $4: 1$, according to a previous publication. ${ }^{24}$ DLS analysis showed the formation of mRNA polyplexes with a diameter of $\sim 150 \mathrm{~nm}$ with a narrow distribution (polydispersity index (PDI) < 0.15), and with a positive zeta potential of $16 \mathrm{mV}$. Next, the prepared mRNA

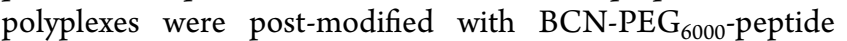
through copper-free click conjugation between the BCN and $\mathrm{N}_{3}$ moieties, generating stable covalent bonds between the PEG-peptides (forming the polyplex shell) and the polyplex core. To optimize the surface peptide density, two different amounts of $\mathrm{BCN}-\mathrm{PEG}_{6000}$-peptide conjugates were added to the mRNA polyplexes: $30 \%$ or $60 \% \mathrm{BCN} / \mathrm{N}_{3}$ molar ratio, respectively. In the last step, interchain disulfide cross-linking of the polyplexes was induced by the addition of DTT at a $50 \%$ molar equivalent of the PDS groups of the polymer, yielding final peptide-modified mRNA polyplexes (named as PPxPeptide). Finally, PPx formulations were freeze-dried in the presence of $5 \%$ sucrose and stored at $4{ }^{\circ} \mathrm{C}$ no longer than 2 weeks before use. Freeze-drying and cold storage did not result in a change in the particle size distribution of PPx after their redispersion in buffer. Similarly, the mRNA polyplexes postmodified with $B C N-P_{50} G_{500} \mathrm{COOH}$ at a $60 \% \mathrm{BCN} / \mathrm{N}_{3}$ molar ratio were prepared using the same steps, yielding PEGylated mRNA polyplexes (named as $\mathrm{Px}$ ) as a control.

The size and zeta potential of the control Px and various PPx formulations were determined. As shown in Figure 1B, after post-PEGylation, the size of Px was around $155 \mathrm{~nm}$, which is slightly higher than the size of mRNA polyplexes before PEGylation $(140 \mathrm{~nm})$. The decrease of zeta potential after PEGylation (from 16 to $-5 \mathrm{mV}$ ) confirmed the success of conjugation of PEG to the preformed mRNA polyplexes (Figure 1C). After modification with either the LEDE or melittin peptide, independent of the added amount (low or high) of peptides, the size of PPx was around 150-200 nm, with a relatively low polydispersity (PDI, $0.15-0.3$ ), which is similar as the size of Px that has no peptide attached. In contrast, the size of GALA modified PPx significantly increased from 140 to $350-400 \mathrm{~nm}$ together with an increased PDI of around 0.4 . This increase in size and PDI is presumably due to the negative charge of GALA (Figure 1A), which might be caused by interpolyplex cross-linking due to the presence of

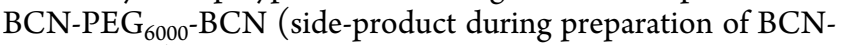
PEG-GALA) and the low repulsive forces between the polyplexes because of their low zeta-potential. This assumption was confirmed by nanoparticle tracking analysis (NTA), a technique that allows the simultaneous analysis of individual particles in suspension and gives information on the true size distribution (Figure S3). Px showed a similar particle size as found with DLS analysis $(\sim 150 \mathrm{~nm})$, whereas PPx-GALA clearly showed two populations with average sizes around 200 and $300 \mathrm{~nm}$ and the peak around $300 \mathrm{~nm}$ can be ascribed to inter-cross-linking of two polyplex nanoparticles of $\sim 150 \mathrm{~nm}$. Compared to Px that had a negative zeta potential, the zeta potential of PPx-LEDE and PPx-Melittin polyplexes was nearneutral with a slight increase in zeta potential when the highest amount of peptide was coupled. This is because these peptides have a net positive charge at neutral $\mathrm{pH}$ (Figure 1A). In contrast, PPx-GALA polyplexes have a negative zeta potential due to the net charge of -7.9 of this peptide at neutral $\mathrm{pH}$ (Figure 1C). The zeta potential of PPx-GALA decreases when the highest amount of GALA peptide was added during formulation (low vs high: -5 vs $-8 \mathrm{mV}$ ), which implied that indeed more GALA peptides were conjugated to the surface of mRNA polyplexes at the higher peptide feed.

Peptide-Mediated mRNA Delivery to Antigen Presentation Cells. To be able to quantify the transfection 
A1

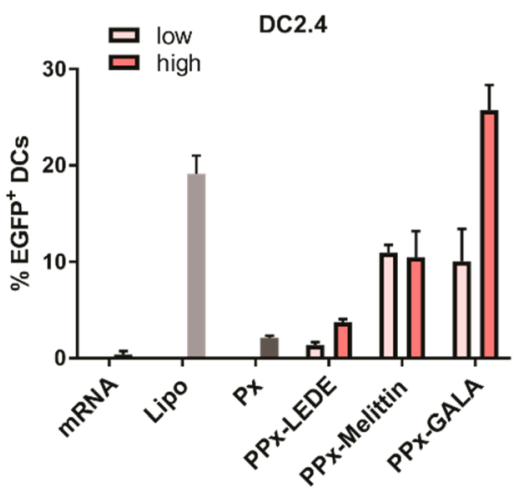

A2

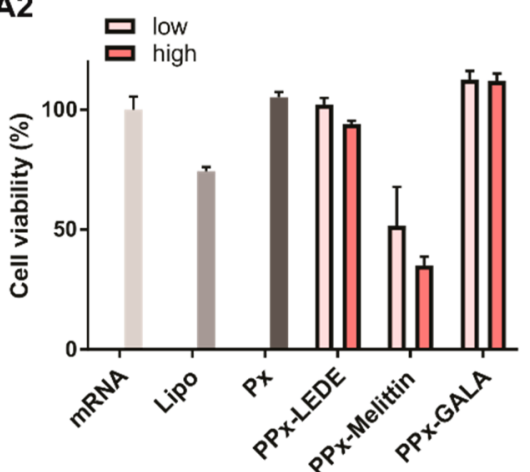

D

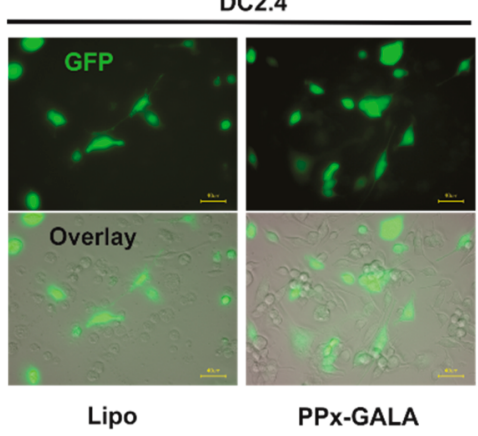

B1

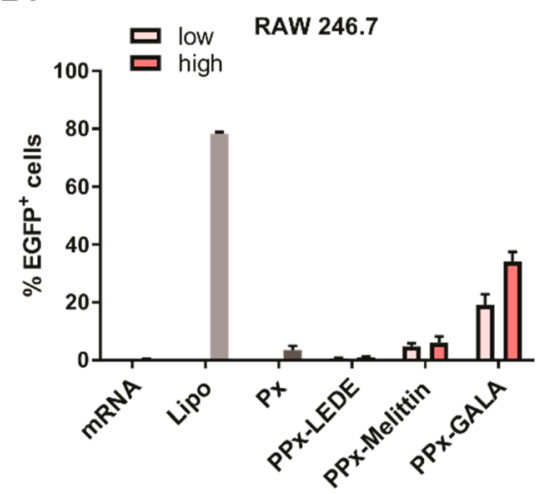

B2

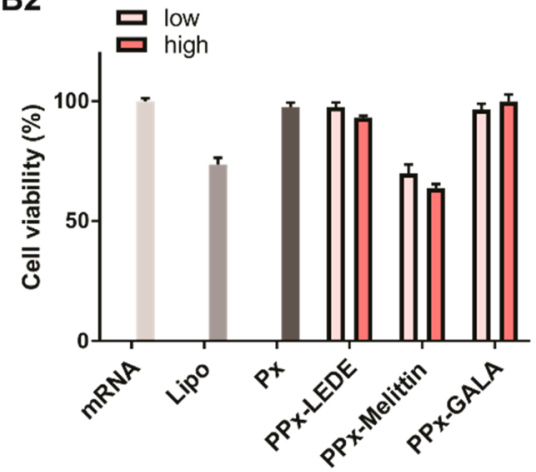

RAW 246.7

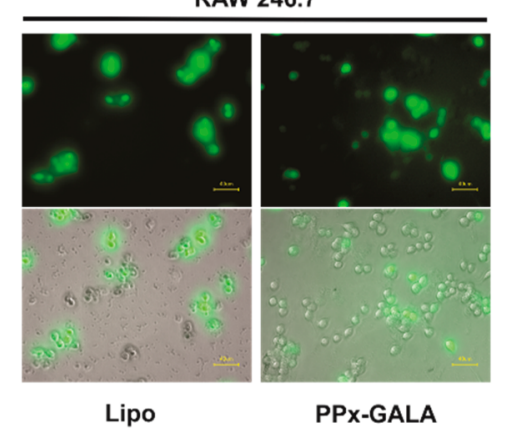

C1

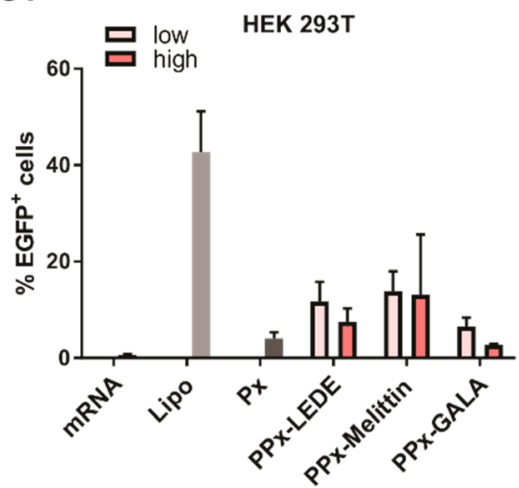

C2

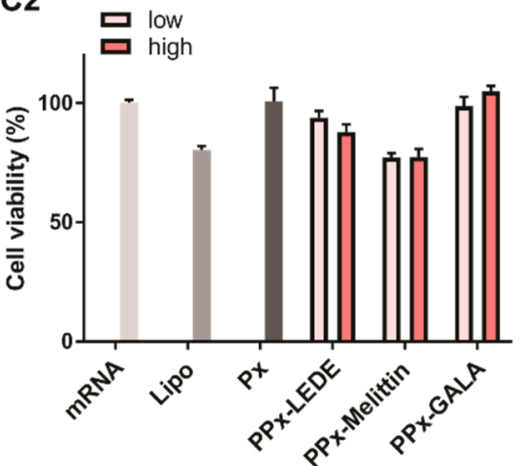

E

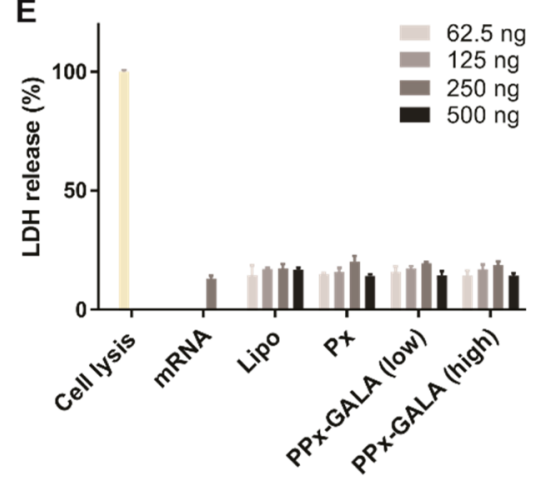

Figure 2. Evaluation of PPx formulations for EGFP mRNA delivery. EGFP expression (upper panels) detected by flow cytometry and normalized cell viability (lower panels) in comparison to untreated cells (100\% cell viability) determined with the AlamarBlue assay using DC2.4 (A), RAW246.7 (B), and HEK 293T(C) cells $24 \mathrm{~h}$ after incubation with free mRNA or PPx. (D) Epifluorescence microscopy images showing EGFP fluorescence alone and a bright-field overlay of DC2.4 (left panel) and RAW 246.7 cells (right panel) treated with mRNA complexed with Lipofectamine 2000 (Lipo), Gala modified mRNA polyplexes (PPx-GALA, high). (E) Lactate dehydrogenase (LDH) assay of DC 2.4 cells after incubation for $4 \mathrm{~h}$ in the absence of serum with the indicated formulations and with various amounts of mRNA added per well. The cells were transfected with $250 \mathrm{ng} \mathrm{mRNA} /$ well in 96-well plates. Data are the mean $\pm \mathrm{SD}, n=3$. Size bar corresponds to $40 \mu \mathrm{m}$.

activity of the different PPx formulations, mRNA encoding for EGFP was used. Flow cytometry analysis of EGFP fluorescence following mRNA delivery allows for simultaneous quantification of the fraction of cells exhibiting above-baseline levels of fluorescence (percent transfection) as well as shifts in the mean fluorescence intensity of the entire cell population. mRNA expression after incubation of the cells with PPx in the absence of serum was compared with expression obtained with EGFP mRNA lipoplexes based on the commercial agent Lipofectamine 2000 (Lipo, positive control) as well as Px. The cells were transfected with PPx modified with low or high amounts of peptides. Bone marrow derived dendritic cell line DC 2.4, macrophage cell lines RAW246.7 and normal cell line HEK 293T were used to evaluate the transfection activities of the different PPx formulations (Figure 2 and S4). As shown in
Figure 2A, modest levels of EGFP expression ( 20\%) were observed in DC 2.4 cells when transfected with Lipo, which is in line with previously reported work $(\sim 25 \%) .{ }^{23}$ Naked mRNA and the Px formulation showed no transfection at all. The PPxLEDE or PPx-Melittin formulations both exhibited a weak EGFP expression $(<12 \%)$, irrespective of the amount of peptide grafted on the surface. Interestingly, PPx-GALA formulations with a high peptide density showed the highest EGFP expression with $28 \%$ transfection efficiency, and which is more than 2 times higher than the PPx-GALA formulations with a low peptide density. A similar trend was also observed in RAW246.7 cells (Figure 2B), with lipofectamine and PPxGALA being the only formulations that showed transfection but with higher levels of transfection as compared to DC 2.4 cells. By increasing the GALA density on the surface of PPx, 
A

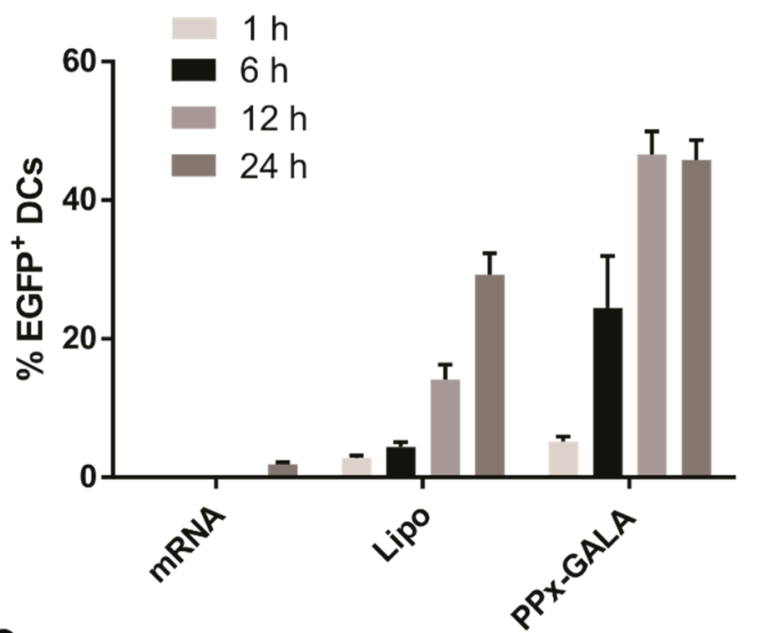

C

Lipo
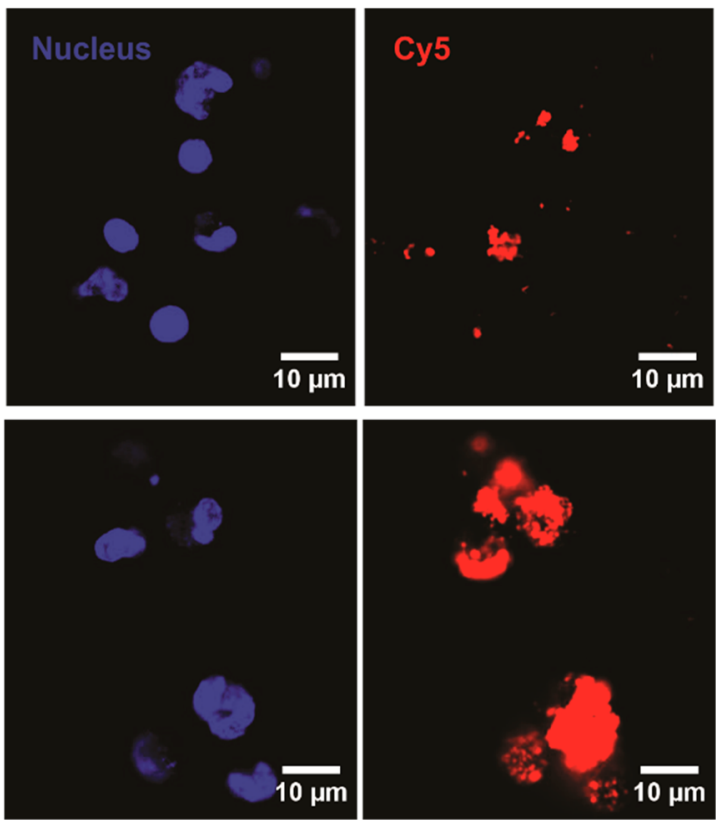

B
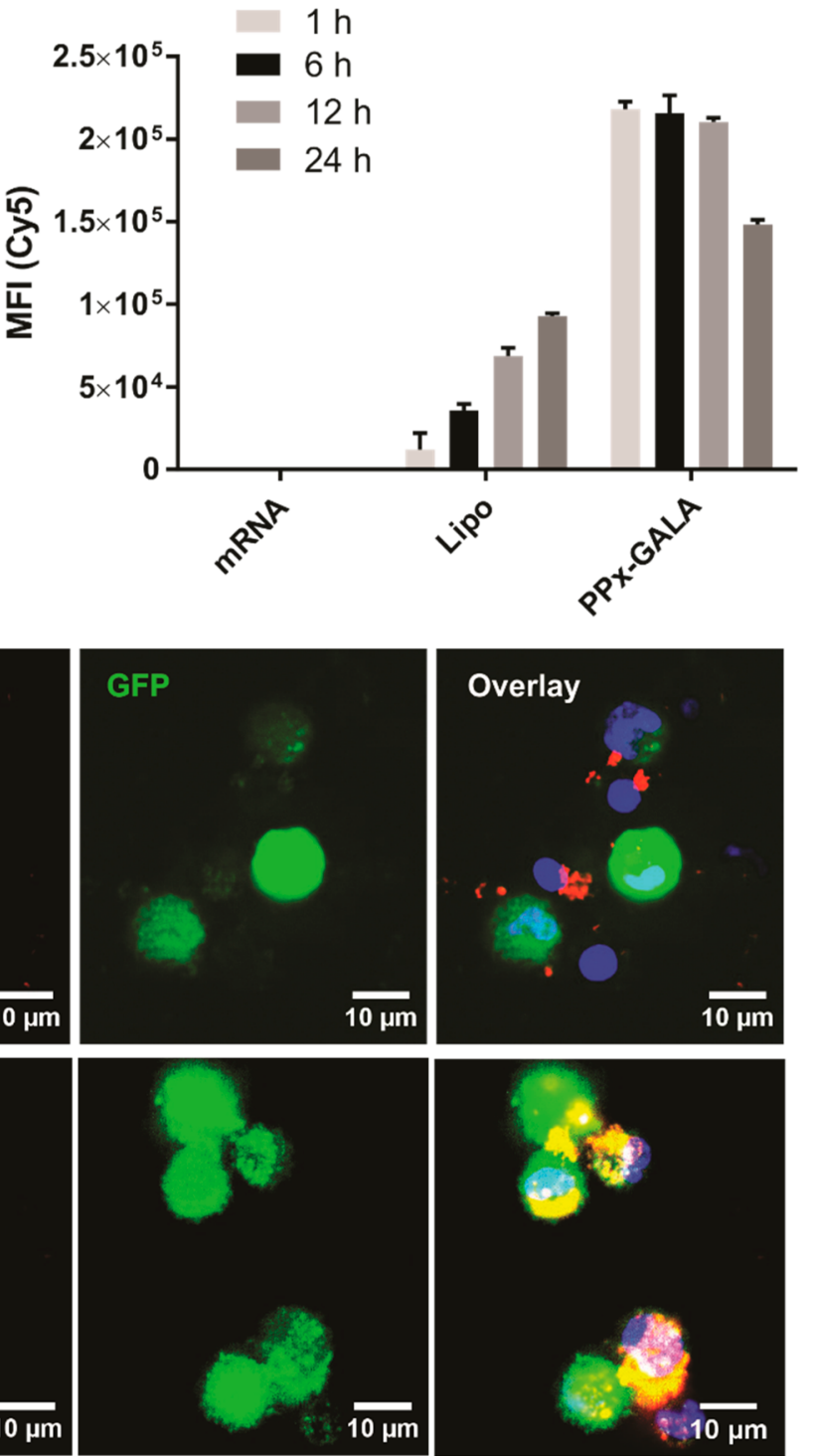

Figure 3. Transfection (A) and cellular uptake (B) kinetics of Cy5-EGFP mRNA on D1 cells following incubation with the indicated formulations by flow cytometry. (C) Confocal microscopy of D1 cells incubated with Cy5-EGFP-mRNA complexes after $12 \mathrm{~h}$. The cells were transfected in the absence of serum and were incubated with $250 \mathrm{ng} \mathrm{mRNA} /$ well in 96-well plates. Data are the mean $\pm \mathrm{SD}, n=3$. Bar indicates $10 \mu \mathrm{m}$.

the transfection efficiency increased from $23 \%$ to $36 \%$. In contrast, HEK293T cells incubated with PPx-LEDE and PPxmelittin induced moderate levels of EGFP expression (10$20 \%$ ), whereas incubation with PPx-GALA showed expression in less than $5 \%$ of cells (Figure 2C). The EGFP expression was also confirmed by epifluorescence microscopic analysis (Figure 2D).

The possible cytotoxicity of the different PPx formulations was evaluated by an AlamarBlue assay using DC2.4, RAW 264.7 macrophages, and HEK 293T cells (Figure 2). Cells were incubated with the PPx formulations for $24 \mathrm{~h}$, after which cell viability was quantified based on their total metabolic activity resulting in reduction of the AlamarBlue reagent. In all three cell lines, incubation with the lipofectamine formulation showed acceptable levels of cytotoxicity with $>75 \%$ cell viability. Compared with RAW 246.7 and HEK 293T cell lines, PPx-Melittin showed higher toxicity toward DC2.4 (40\% viability). Importantly, the PPx-GALA and PPx-LEDE formulations exhibited high cytocompatibility (>95\% viability) in all three cell lines. We further evaluated in DC2.4 cells the cell membrane-destabilizing capability of PPx-GALA at different concentrations using a lactate dehydrogenase $(\mathrm{LDH})$ release assay. As shown in Figure 2E, released LDH from cells incubated with the indicated formulations was comparable to naked mRNA, again pointing to an excellent cytocompatibility of PPx-GALA. Overall, PPx-GALA with high GALA density was identified as best formulation as it was able to specifically transfect antigen presentation cells like macrophages and dendritic cells with a superior cytocompatibility. This formulation was therefore selected for further testing.

We further examined the capacity of PPx-GALA to transfect the spleen-derived D1 cell line, a growth factor-dependent cell line derived from splenic C57BL/6 mouse DCs that behaves like freshly isolated bone marrow DCs. ${ }^{32,33} \mathrm{D} 1$ cells were transfected with PPx-GALA, loaded with Cy5-EGFP mRNA both in the presence and absence of serum. When the D1 cells were incubated with PPx-GALA in the absence of serum, $50 \%$ of cells expressed EGFP, which is significantly higher than 

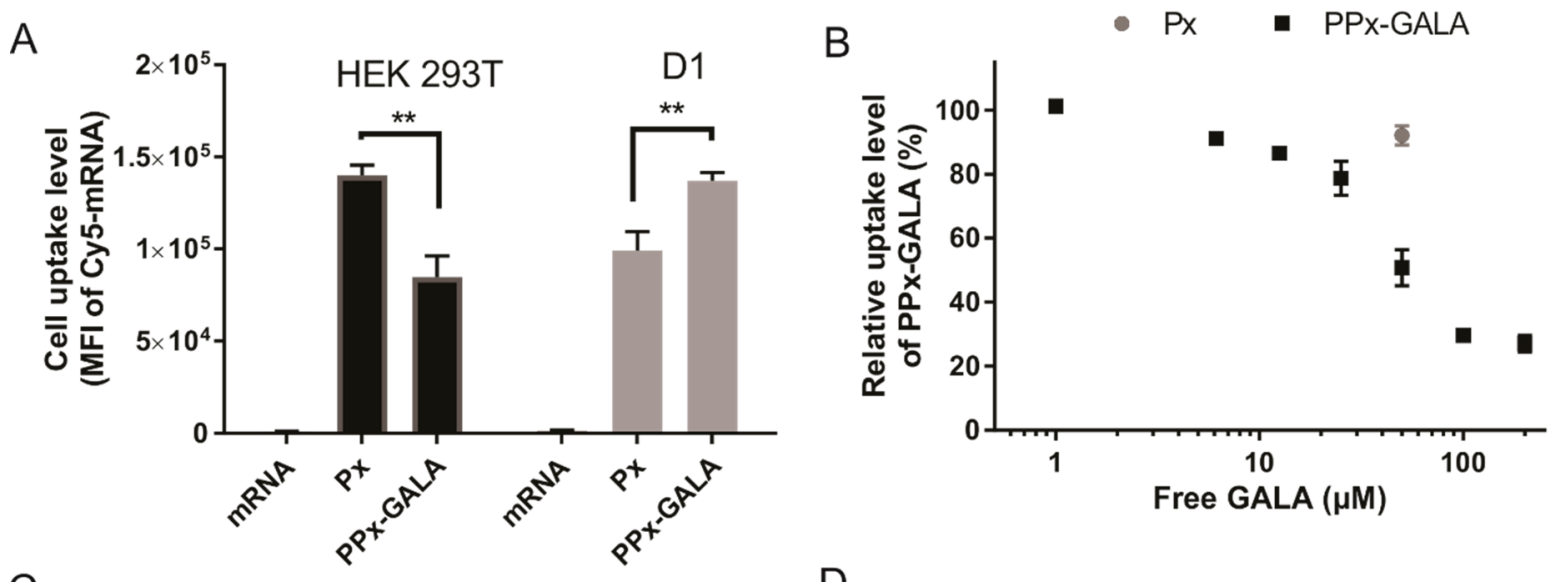

C

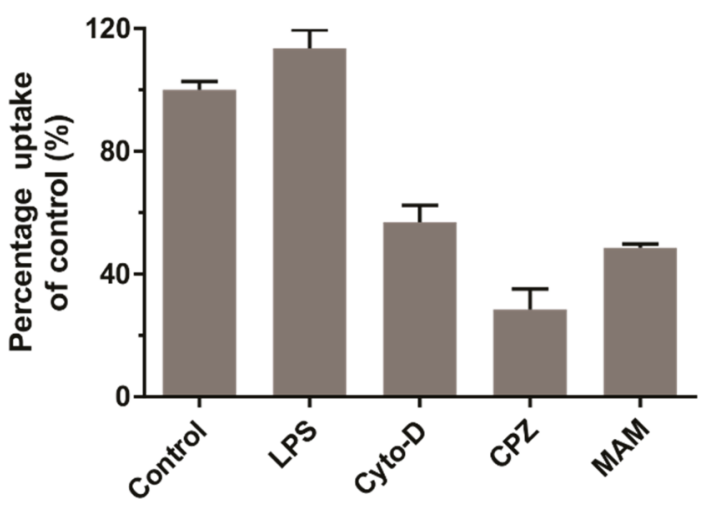

$\mathrm{D}$

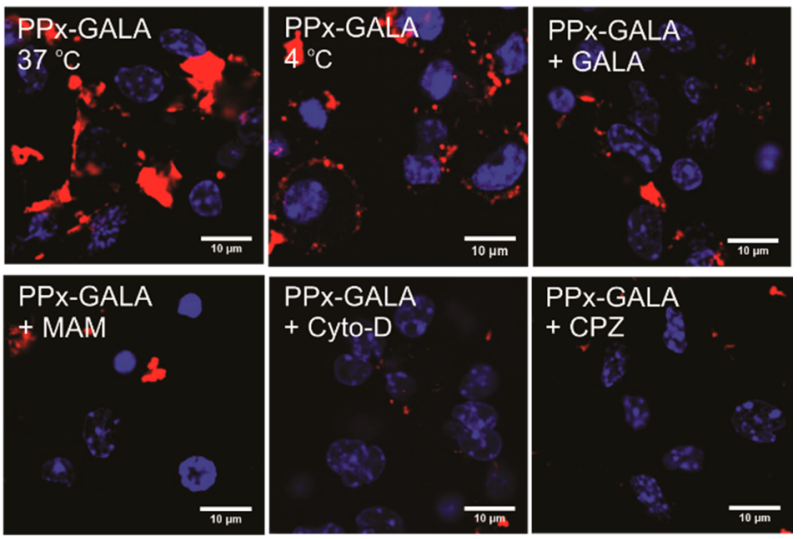

Figure 4. Cellular uptake mechanism of PPx-GALA. (A) Cellular uptake of naked Cy5-luc_mRNA, Px and PPx-GALA by HEK293T (left) and D1 (right) cells after $1 \mathrm{~h}$ incubation in the presence of serum. (B) Inhibition of the intracellular uptake of Px and PPx-GALA by free GALA. The cellular uptake of Px or PPx-GALA by D1 was determined by FACS after incubation $1 \mathrm{~h}$ at $37^{\circ} \mathrm{C}$ in the presence of GALA (1-120 $\left.\mu \mathrm{M}\right)$. (C) Inhibition of D1 cellular uptake of PPx-GALA. D1 cells were incubated with PPx-GALA Cy5-luc_mRNA polyplexes for $2 \mathrm{~h}$ in the presence of LPS, Cytochalsin D (Cyto-D), Chlorpromazine (CPZ) and Maackia amurensis agglutinin (MAM). (D) Confocal microscopy of D1 cells $2 \mathrm{~h}$ after incubation with PPx-GALA in the presence of indicated molecules at 37 or at $4{ }^{\circ} \mathrm{C}$. Cell nuclei were stained with Hoechst (blue), Cy5-luc_mRNA is shown in red. In all the studies, $250 \mathrm{ng} \mathrm{mRNA} /$ well was added in 96-well plate. Data are the mean $\pm \mathrm{SD}, n=3-5$. Bar indicates $10 \mu \mathrm{m}$.

that of Lipo ( 28\%) (Figure S5A). In contrast, Px with the same amount of unconjugated GALA showed no transfection at all, which indicates that immobilized GALA peptides contributed to the enhanced transfection. In the presence of serum, the relative transfection efficiency significantly decreased, from $50 \%$ to $15 \%$ for PPx-GALA and from $30 \%$ to $20 \%$ for the Lipo formulation. The same trends were also observed by fluorescence microscopy (Figure S5B). This decrease in transfection efficiency in the presence of serum is partly due to the reduced cellular uptake, with a $23 \%$ and $46 \%$ decrease in mRNA uptake for Lipo and PPx-GALA, respectively (Figure S5C).

mRNA Expression Kinetics in Dendritic Cells. Next, kinetics of cellular uptake of PPx-GALA by D1 cells and subsequent mRNA expression was investigated (Figure 3). Upon incubation of D1 cells with PPx-GALA in the absence of serum, transfection reached $\sim 20 \%$ EGFP-positive cells at $6 \mathrm{~h}$, and reached $45 \%$ of transfection at $12 \mathrm{~h}$, which sustained for $24 \mathrm{~h}$ (Figure 3A). In strong contrast, the D1 cells already showed maximum cellular uptake of PPx-GALA after $1 \mathrm{~h}$ incubation and lasted to $12 \mathrm{~h}$, the Cy5-EGFP mRNA intensity inside the cells then decreased after $24 \mathrm{~h}$ incubation (Figure $3 \mathrm{~B})$. On the other hand, the percentage of cells expressing EGFP and cellular uptake after Lipo transfection was still increasing at $24 \mathrm{~h}$ of incubation. As shown in Figure 3B, the cellular uptake level of PPx-GALA was 18 and 3-fold higher than Lipo at 1 and $12 \mathrm{~h}$ of incubation, respectively. The same results were observed by confocal microscope images (Figure 3C). D1 cells incubated with PPx-GALA showed much higher Cy5-EGFP uptake than cells incubated with the Lipo formulation. Despite the rapid delivery of high amounts of mRNA into D1 cells upon incubation with PPx-GALA, the mRNA expression peak was observed at only $12 \mathrm{~h}$, which is later than the typical mRNA expression peak at 6-7 h posttransfection in DCs or other cell types. ${ }^{34,35}$ The rapid and sustained uptake of PPx-GALA compared to Lipo points toward a different uptake mechanism for PPx-GALA by dendritic cells that leads to functional delivery of mRNA at later time points.

DC Cellular Uptake Mechanisms of PPx-GALA. To elucidate potential mechanisms that underlie efficient DC uptake by PPx-GALA, the uptake level of PPx-GALA was compared to Px in D1 and HEK 293T cells. After $1 \mathrm{~h}$ incubation, HEK 293T cells internalized higher amounts ( 1.7-fold) of Px compared to PPx-GALA (Figure 4A). Conversely, D1 showed higher uptake of PPx-GALA compared to Px. It has been reported that particles with the size range 200-500 nm are more favorable for uptake by dendritic cells; ${ }^{36-38}$ thus higher cellular uptake of PPx-GALA compared to $\mathrm{Px}$ in D1 cells might be ascribed to the size difference (350 
A
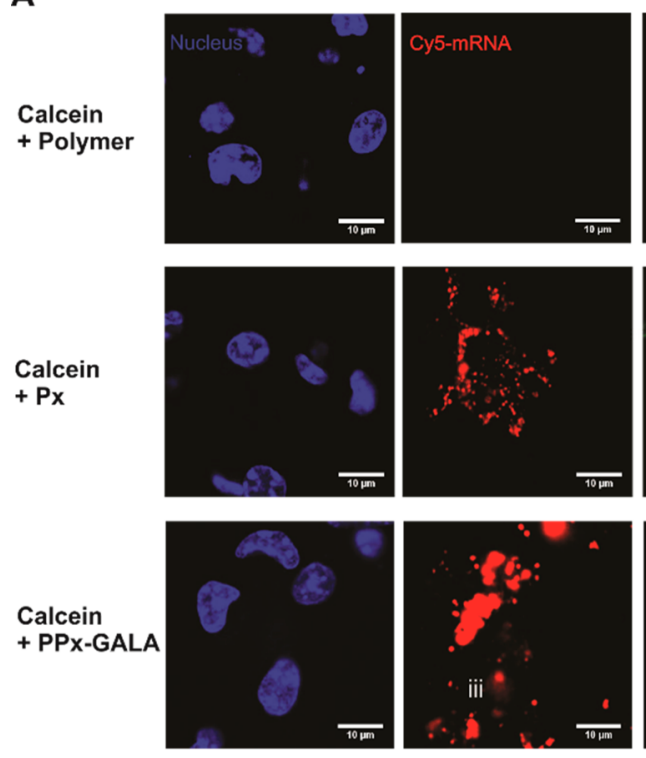
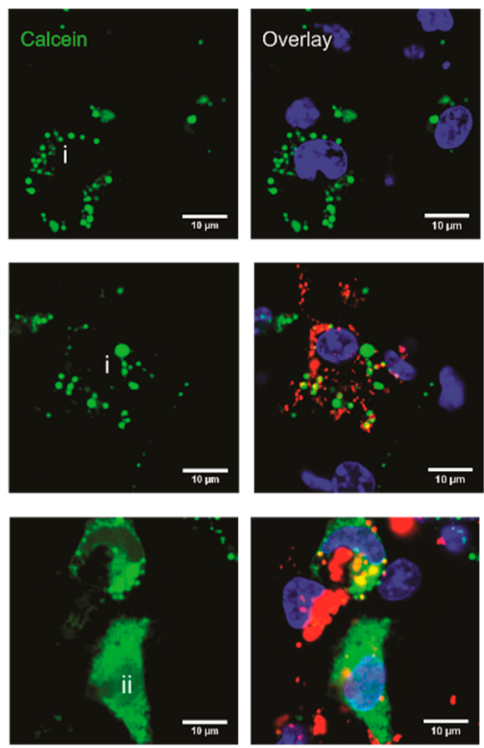

B
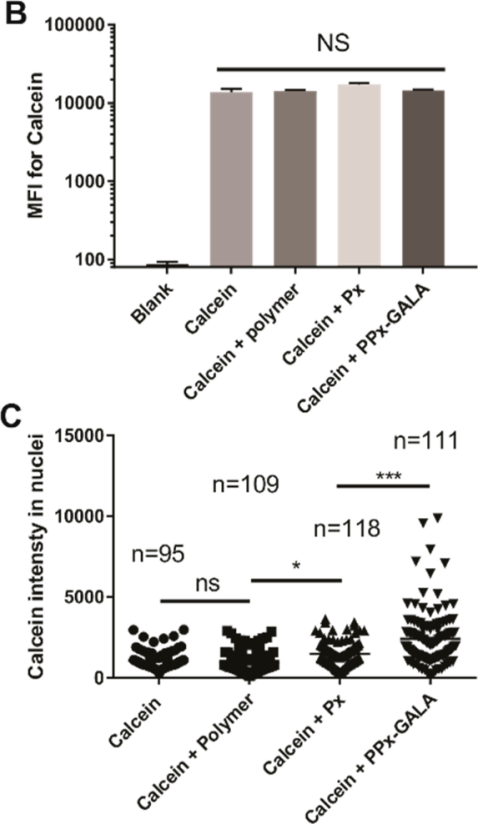

Figure 5. PPx-GALA polyplexes facilitate the delivery of the membrane-impermeable fluorescent molecule calcein into the cytosol of dendritic cells. Confocal microscopy (A) and flow cytometry analysis $(n=4)(B)$ of the cellular uptake of calcein in D1 cells after $3 \mathrm{~h}$ in the presence of serum at $37{ }^{\circ} \mathrm{C}$ after incubation of polymer, Px, and PPx-GALA in the presence of $150 \mu \mathrm{g} / \mathrm{mL}$ calcein (blue, nuclei; red, Cy5-luc mRNA; green, calcein). Scale bar: $10 \mu \mathrm{m}$. (C) The mean fluorescence intensity of calcein in D1 cell nuclei measured by ImageJ from confocal microscopy pictures. Data are the mean $\pm \mathrm{SD}$.

$\mathrm{nm}$ for PPx-GALA versus $150 \mathrm{~nm}$ for Px). However, another possibility is that the PPx-GALA entered DCs via receptormediated endocytosis, which is often much faster compared to adsorption-mediated endocytosis or macropinocytosis. ${ }^{39}$ GALA is a 30 -amino-acid synthetic peptide with a glutamic acid-alanine-leucine-alanine (EALA) repeat, that resembles the putative fusion peptide domain of Influenza virus hemagglutinin 2 (HA2) with $\mathrm{pH}$-dependent membrane fusion ability. ${ }^{28,40}$ Recent studies have shown that GALA-modified lipid nanoparticles could actively target sialic acid-terminated sugar chains on lung endothelial cells. ${ }^{41,42}$ Dendritic cells also present a very high amount of sialic acid-containing glycans on the cell surface. ${ }^{43,44}$ Therefore, in light of these findings, we hypothesize that PPx-GALA polyplexes are able to actively target the DCs via sialic acid-terminated glycans mediated endocytosis.

To test this hypothesis, a competition assay was conducted to determine whether free GALA in the cell culture medium inhibits cellular uptake of PPx-GALA. As shown in Figure 4B, free GALA significantly lowered the uptake of PPx-GALA mRNA polyplexes. The competition was dose-dependent and with an $\mathrm{IC}_{50}$ of around $50 \mu \mathrm{M}$. In contrast, preincubation of dendritic cells with same amount of GALA has negligible effect on the cellular uptake of Px. These results suggested that GALA peptides on the surface of mRNA polyplexes do indeed play a role in cellular uptake. To test whether the sialic acidterminated sugar chains on the dendritic cells are involved in PPx-GALA uptake, a plant lectin Maackia amurensis agglutinin (MAM) ${ }^{45}$ which specifically binds to sialic acid, was incubated with the cells before adding PPx-GALA. It is important to note that blocking sialic acid residues with MAM lectin is to be preferred above sialidase treatment, as the removal of sialic acid residues on the DC surface can stimulate the phagocytic ability of these cells as was previously reported. ${ }^{46,47}$ As shown in Figure $4 \mathrm{C}$, the incubation of cells with MAM reduced the cellular uptake level of PPx-GALA by 50\%. On the other hand, preincubation of MAM did not significantly influence the cellular uptake levels of Lipo and Px (Figure S6), indicating that the inhibition of the uptake of PPx-GALA by MAM does not appear to be due to a nonspecific perturbation of cellular function. Similar trends were also observed in confocal microscopy images (Figure 4D). Importantly, when the DCs were incubated with PPx-GALA at $4{ }^{\circ} \mathrm{C}$ for $1 \mathrm{~h}$, a clear signal of red fluorescence was observed at the cell membrane because of PPx-GALA binding. Considering the negative surface charge of PPx-GALA formulation $(-7 \mathrm{mV})$ and that active endocytosis is abolished at $4{ }^{\circ} \mathrm{C}$, nonspecific binding by electrostatic interaction or nonspecific uptake mechanisms such as macropinocytosis can be excluded. Instead, the association of PPX-GALA to the DCs is most likely caused by cell surface receptor-specific binding. These results collectively suggest uptake of the PPx-GALA through sialic acid-terminated glycan-mediated endocytosis.

Furthermore, the mechanism of cellular uptake was also examined by treating D1 cells with inhibitors of endocytosis, macropinocytosis and phagocytosis. It is well documented that mature DCs show low levels of macropinocytosis, ${ }^{48}$ whereas receptor-mediated endocytosis and phagocytosis still remain highly active. ${ }^{49}$ Maturation of D1 cells with lipopolysaccharide (LPS) had no effect on the level of internalization of PPxGALA as compared to control (Figure 4C). Also, PPx-GALA taken up by D1 cells showed no colocalization with the macropinosome marker dextran (Figure S7). ${ }^{50}$ In comparison, cytochalasin D (CytoD), an inhibitor of phagocytosis and chlorpromazine (CPZ), a clathrin-mediated endocytosis inhibitor, significantly inhibited cellular uptake of DCs by $40 \%$ and $70 \%$, respectively (Figure 4C,D). Altogether, these findings demonstrate that receptor-mediated endocytosis triggered by sialic acid binding as well as phagocytosis are the major uptake pathways of PPx-GALA in D1 cells. 
A
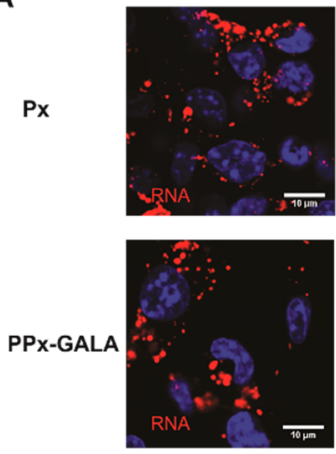
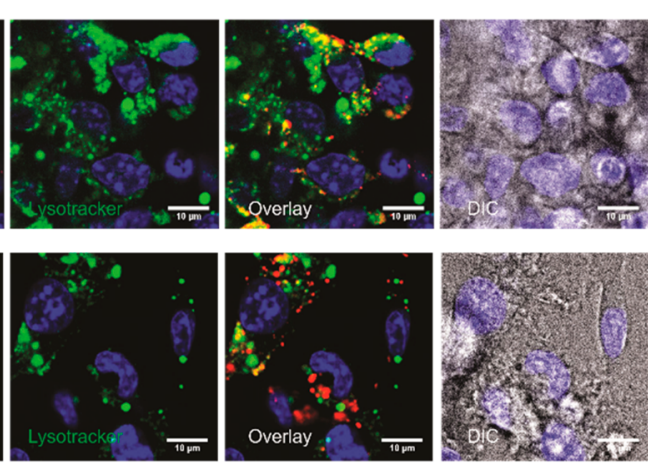

B

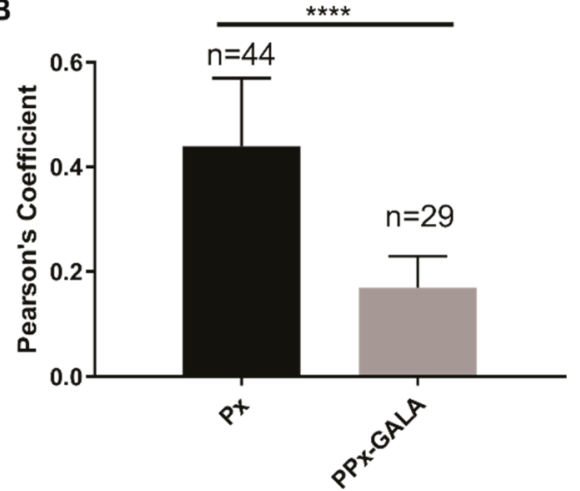

Figure 6. Lysotracker staining of PPx-GALA mRNA formulations in D1 cells. (A) Confocal microscopy of D1 cells $3 \mathrm{~h}$ after incubation with Px or PPx-GALA containing Cy5-luc_mRNA in the presence of serum at $37^{\circ} \mathrm{C}$. The endolysosomes were labeled with lysotracker green, yellow puncta in the overlay images indicate colocalization of mRNA (red) and lysotracker (green). Bar indicates $10 \mu \mathrm{m}$. (B) Averages of Cy5-luc mRNA colocalization coefficients with lysotracker of images from A. Images were analyzed by ImageJ with the Pearson correlation coefficient. ${ }^{53}$ Data are the mean \pm SD.
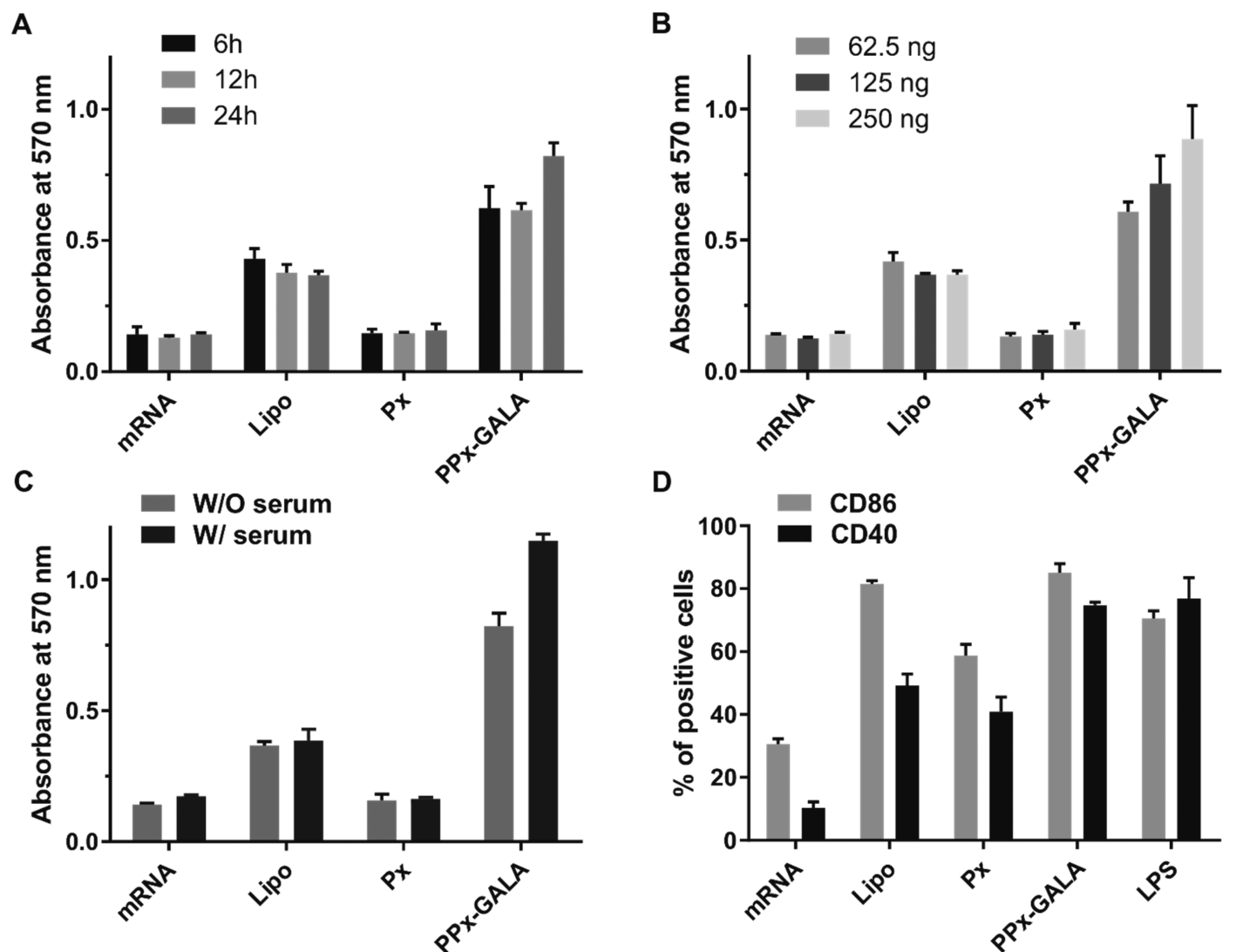

Figure 7. B3Z $\mathrm{T}$ cell activation by transfected D1 dendritic cells. D1 cells were incubated with free mRNA and the indicated mRNA polyplexes encoding ovalbumin (OVA) for indicated lengths of time (A), or different mRNA dosages at a fixed incubation time (24 h) (B) and different transfection conditions (C), then cocultured with B3Z T cells for $24 \mathrm{~h}$. T cell activation was then quantified based on $\beta$-galactosidase activity. (D) Percentage of D1 cells expressing CD40 and CD86 in response to incubation $24 \mathrm{~h}$ with the indicated formulations, LPS ( $1 \mu \mathrm{g} / \mathrm{mL})$ was used as positive control. Unless specified, all experiments were conducted with mRNA dose of $250 \mathrm{ng} /$ well. Data are the mean $\pm \mathrm{SD}, n=3$.

Intracellular Trafficking Process of PPx-GALA. At neutral $\mathrm{pH}, \mathrm{GALA}$ is water-soluble and converts from a random coil to an amphipathic $\alpha$-helix when the $\mathrm{pH}$ is lowered to 5.0. This conformational change enables binding and insertion of the GALA peptide into the lipid membrane compartment causing membrane leakage. ${ }^{28}$ To test the endosome-disruptive capacity of PPx-GALA, D1 cells were incubated with PPx-GALA in the presence of calcein $(150 \mu \mathrm{g} /$ $\mathrm{mL}$ ) for $1 \mathrm{~h}$ at $37^{\circ} \mathrm{C}$. Calcein is a membrane-impermeant fluorescent small molecule that can be taken up into endocytic vesicles to make them fluorescent. ${ }^{51,52}$ Cells treated with calcein alone or $\mathrm{Px}$ showed a punctuate distribution of fluorescence indicative of endolysosomal compartmentalization of the dye (Figure 5A, i). In contrast, when cells were incubated with PPx-GALA in the presence of calcein, a diffused calcein fluorescence throughout the cytosol and nucleus was observed (Figure 5A, ii). Only part of Cy5-mRNA showed a weak diffused pattern remine very closely to the site of leaking 


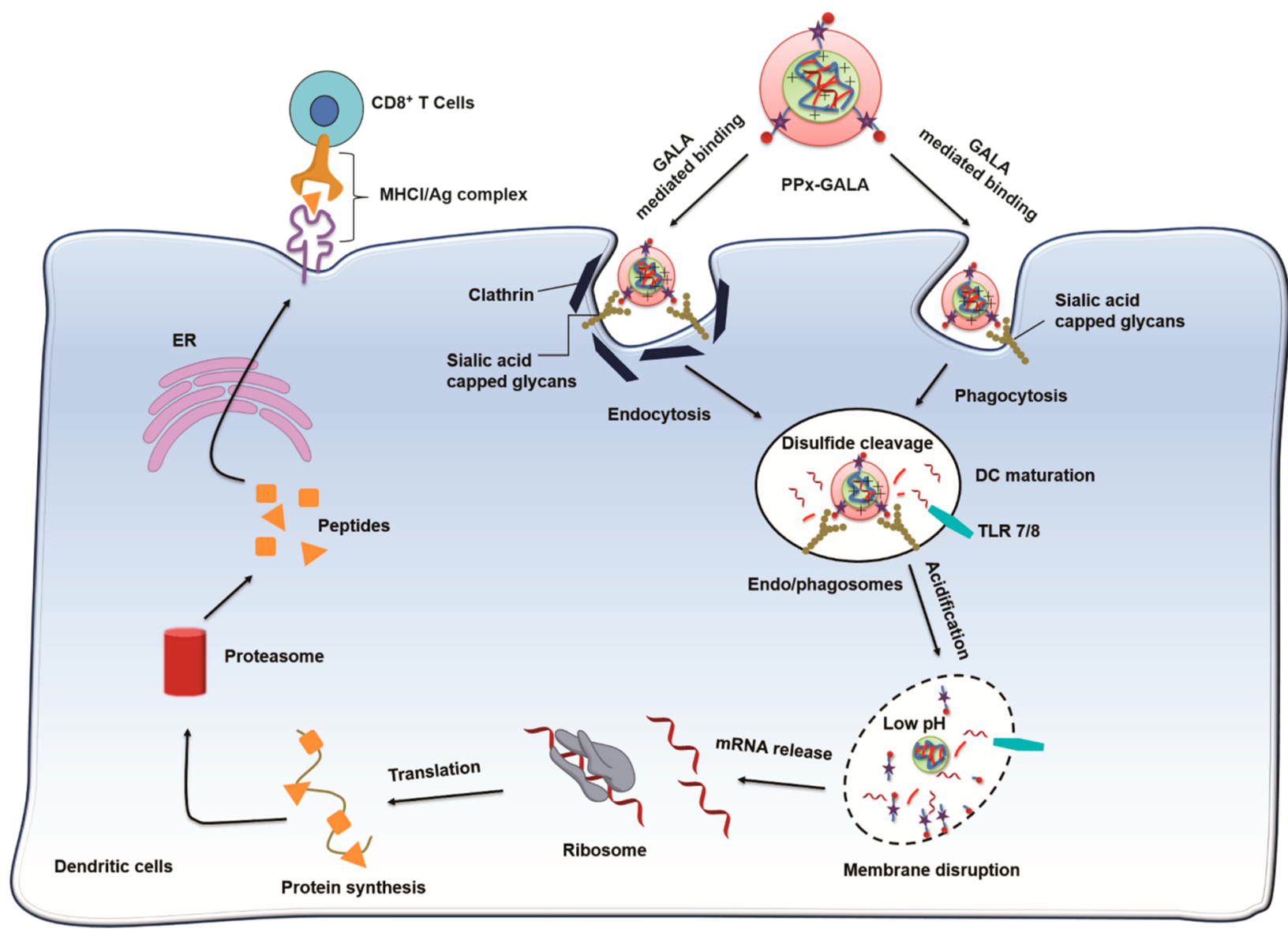

Figure 8. Proposed intracellular trafficking pathway of PPx-GALA mRNA polyplexes. The GALA peptide on the out-layer of polyplexes binds to the sialic acid capped glycans on the surface of DCs, followed by internalization by endo/phagocytosis. The disulfide bonds cross-linker inside polyplexes start to break down due to the presence of different thiols and reductive enzymes, ${ }^{65}$ and mRNA is gradually released from polyplexes and activated TLR7/8 receptor. The decreasing $\mathrm{pH}$ in endo/phagosomes also increases the helical content of GALA, leading to membrane disruption and to subsequent cytosolic release of mRNA, resulting in the induction of protein expression. The expressed endogenous antigen protein is processed by proteasome and presented to MHC I on the cell surface.

endosome (Figure 5A, iii). To exclude the possibility that PPxGALA might have destabilized the cell membrane allowing calcein to diffuse directly into the cytosol, total cell-associated calcein fluorescence was determined by flow cytometry (Figure 5B). The coincubation of calcein with PPx-GALA did not increase the mean fluorescence intensity (MFI) of the cells compared to control groups, excluding the option of direct influx of calcein over the cell membrane. Since calcein can freely diffuse from the cytosol into the nucleus, this organelle can be taken as a clean region of interest (ROI) to quantify cytosolic calcein release with ImageJ. Figure 5C shows the fluorescence intensity of calcein inside the nucleus of cells as measured by confocal microscopy. The average calcein fluorescence of nuclei from cells incubated with PPx-GALA was significantly higher than that of cells incubated with Px or with the soluble polymer used to prepare PPx-GALA. Based on these data, it is safe to conclude that the observed diffuse calcein fluorescence in the DCs is due the leakage of calcein from endolysosomes caused by the immobilized GALA peptides on internalized PPx-GALA.

The final fate of mRNA polyplexes was also evaluated by staining late-endosome/lysosome with lysotracker (green), and Px polyplexes without endosomal escape ability were used as control (Figure 6A). As expected, the confocal images of cells transfected with PPx-GALA displayed spreading red regions into the cytoplasm and showed lower colocalization with lysotracker compared with Px (Figure 6B). Lysotracker as a weakly basic amine can selectively accumulate into acidic compartments such as lysosomes. The lower colocalization with mRNA is most likely due to the GALA-disrupted acidic compartments resulting in an increase in $\mathrm{pH}$ of the endosomal lumens, which may lead to quenching and/or redistribution of the fluorescence of lysotracker. ${ }^{54}$ These results strongly suggest that the presence of GALA on the surface of mRNA polyplexes facilitate endosomal escape.

PPx-GALA OVA-mRNA Polyplexes Stimulate DC Antigen Presentation and Promote DC Maturation. Antigen processing and presentation were analyzed using D1 cells incubated with PPx-GALA and loaded with mRNA encoding ovalbumin. An in vitro MHC I antigen presentation assay was performed using the $\mathrm{B} 3 \mathrm{Z} C D 8^{+} \mathrm{T}$ cell hybridoma, which produces $\beta$-galactosidase upon recognition of the ovalbumin CD8 epitope (SIINFEKL) presented in the context of MHC I H-2 $\mathrm{K}^{\mathrm{b}}$ on the surface of D1 cells. ${ }^{55}$ Time course and dose response studies were performed to establish the kinetics of OVA mRNA translation, processing and presentation of the SIINFEKL peptide (Figure 7). As shown in Figure 7A, a $6 \mathrm{~h}$ incubation time of D1 cells with PPx-GALA is enough to detect $\mathrm{T}$ cell activation. At $24 \mathrm{~h}$, the PPx-GALA generated the highest $\mathrm{T}$ cell responses. This was further confirmed by flow 
cytometry, which was used to detect the amount of MHCIOVA epitope on the cell surface by staining DCs with the 25D1.16 monoclonal antibody directed against MHC I H-2K complexes (Figure S8). The kinetics of OVA antigen presentation were similar as for EGFP mRNA expression, which implies that the cytoplasmic protein production and proteasome processing were conducted at the same time. Since a 4 fold decrease in mRNA dose only lead to a minor decrease in $\mathrm{T}$ cell responses (Figure $7 \mathrm{~B}$ ), it can be concluded that the proteasome degradation process is the rate limiting step for antigen presentation. A similar phenomenon was also observed in a previous study, where a mRNA core-lipid shell structured $\mathrm{LPP} / \mathrm{mRNA}$ (encoding for OVA) vaccine was used to transfect DC2.4 with almost 100\% efficiency with EGFP mRNA, but only have around $10 \%$ of DCs displayed MHC I $\mathrm{H}-2 \mathrm{~K}^{\mathrm{b}}$ complexes when transfected. ${ }^{13}$ Surprisingly, when D1 cells were transfected in the presence of serum, PPx-GALA produced a higher $\mathrm{T}$ cell response than when serum was omitted (Figure 7C), despite having a slightly lower EGFP mRNA transfection efficiency (Figure S5). These results suggest that the high mRNA translation efficiency does not necessarily correlate with high $\mathrm{T}$ cell responses.

Subsequently, we evaluated to what extent the OVA mRNA polyplexes PPx-GALA were able to activate DCs. After D1 cells were incubated for $24 \mathrm{~h}$ with PPx-GALA, strong upregulation of the costimulatory markers CD40 and CD86 was observed (Figure 7D). PPx-GALA polyplexes were able to promote DC maturation to the same extent as D1 treated with LPS. The higher DC maturation level of PPx-GALA compared to Px may be due to the higher cellular uptake level because of the GALA targeting ability (Figure 4A). These results indicate that DC maturation is mediated by the self-adjuvant effect of mRNA, and not so much by mRNA expression. In summary, PPxGALA polyplexes are able to efficiently promote DC antigen presentation as well as DC maturation.

\section{SUMMARY}

This study aimed to identify a peptide candidate to facilitate mRNA endosomal escape from APCs using a novel polymerbased mRNA vaccine platform. APCs are known for being notoriously difficult to transfect with nonviral transfection methods. ${ }^{56}$ Here, three different peptides (LEDE, Melittin and GALA) were examined to promote endosomal escape of mRNA polyplexes. We found that GALA-modified mRNA polyplexes were the only formulation that successfully transfected both macrophages and DCs. Optimal exposure of GALA peptides from the surface of polyplexes was achieved by using a post-modification method in which first the mRNA polyplex core was formed, after which a functional shell was introduced using click chemistry. This method prevents shielding of immobilized GALA peptides (Figure 1A) since previous studies have shown that GALA must be present on the surface of particles to exert its function. ${ }^{57}$ Strikingly, the negatively charged PPx-GALA polyplexes were able to transfect both the DC 2.4 murine bone marrow derived dendritic cell line (28\%) and the D1 spleen-derived cell line (50\%) with a transfection efficiency comparable to that of cationic polyplexes ${ }^{23,58,59}$ and lipoplexes. ${ }^{13,15,22}$ The use of GALA peptides has resulted in enhanced pDNA and siRNA transfection in different tumors ${ }^{27,28,60-63}$ and dendritic cells. ${ }^{64}$ However, to the best of our knowledge, this is the first time that GALA modified polyplexes promote mRNA delivery in APCs.
Cellular uptake studies revealed that PPx-GALA efficiently bound to the surface of DCs. Sialic acid residues on membrane proteins and lipids ${ }^{41}$ and GALA peptides on the polyplex seemed to play a role in this binding as preincubation with MAM lectin blocked binding to DCs, whereas polyplexes without GALA did not show any inhibited cellular uptake (Figure 4C,D). Cell membrane binding of PPx-GALA did lead to rapid internalization (Figure $3 \mathrm{~B}$ ). It was unexpected to see that a peptide that was initially selected for its fusogenic properties, also showed selective binding to cell surface proteoglycans on dendritic cells and thus acts as targeting ligand. As depicted in Figure 8, the PPx-GALA mimics the cell entry mechanism of influenza viruses as both bind to sialic acid residues, ${ }^{66}$ are taken up by endocytosis/phagocytosis and trigger endosomal escape of their RNA content. Further proof for a specific interaction between GALA and sialic acid residues was given by dose-dependent binding of PPx-GALA to a variety of tumor cell lines (murine melanoma B16F10, mouse colorectal cancer CT26 and human lung carcinoma $\mathrm{H} 358$ ) that are known to overexpress sialic acid residues to protect them against the immune defense system. ${ }^{67-70}$ As shown in Figure S9, after $24 \mathrm{~h}$ incubation with different tumor cells, PPx-GALA exhibited a much higher cellular uptake compared to Px. However, similar as observed for HEK 293T cells, there was no EGFP expression in these tumor cells. The specific ability to transfect APCs other than the tumor cells and normal cell lines may be due to differences in intracellular routing of internalized PPx-GALA in DCs compared to tumor cells. It is known that DCs have a longer acidification process, ${ }^{71-73}$ which could favor thiol-disulfide exchange ${ }^{65}$ and survival of mRNA in the endosomal compartments. The cleavage of the disulfide bonds accelerated the release of mRNA which will activate the TLR7/8 before being released into the cytosol.

For most lipid-based mRNA vaccines that are predominantly internalized by macropinocytosis, internalization is abrogated upon DC maturation, resulting in a loss of transfection efficiency. ${ }^{1,74,75}$ In contrast, the cellular uptake of PPx-GALA increased around $20 \%$ when DCs were matured with LPS (Figure 4C). Interestingly, it has been described that LPSinduced DC maturation leads to upregulation of sialic acid residues on the cell surface. ${ }^{43,46}$ Therefore, PPx-GALA polyplexes have a great advantage over lipid-based delivery systems if it comes to transfecting DCs.

Since the mRNA used in this study has a length more than 1000 nucleotides (nt), a much bigger molecular than siRNA $(\sim 20 \mathrm{nt})$, it is difficult to directly observe their endosomal escape as mRNA exhibited poor mobility in cytoplasm because of molecular crowding. ${ }^{76}$ To have a better understanding of PPx-GALA intracellular trafficking process, we first examined the leakage properties of endo/phagosome caused by GALA using calcein as indicator molecule (Figure 5). After $3 \mathrm{~h}$ coincubation of PPx-GALA with calcein indeed a significant calcein leakage from endo/phagosomes to the cell nucleus was observed (Figure 5). However, only $23 \%$ of total D1 cells showed calcein fluorescence signal inside nuclei even though all the cells have internalized PPx-GALA (Figure 5C). These results imply that only a small portion of internalized PPxGALA is able to cause endo/lysosome disruption; similar phenomena were found for PEI/pDNA polyplexes ${ }^{77}$ and lipid siRNA formulations. ${ }^{78}$

The ultimate goal was to make a polyplex vaccine that would induce strong $\mathrm{CD}^{+} \mathrm{T}$ cell responses. After investigating the 
antigen presentation kinetics in vitro with OVA mRNA as model antigen, we found that the mRNA protein translation and proteasome degradation is fast and occurred $6 \mathrm{~h}$ after transfection (Figure 7A and Figure S8). The PPx-GALA formulations were able to induce a much stronger $\mathrm{T}$ cell response than the Lipo formulation and was less toxic to the cells (Figure 2). The mRNA used in this study was chemically modified (nucleotides-modified), which have shown to produce high levels of protein, reduce the recognition by TLR7/8 and avoid the release of type I IFNs. 7,15,79 Interestingly, PPx-GALA still efficiently activated DCs to the same level as LPS, which may be related to the very high cellular uptake levels of mRNA that continued even after maturation of the DCs. In conclusion, GALA appears to fulfill a dual task: it binds to sialic acid residues on DCs and after internalization subsequently triggers endosome disruption, thereby helping the mRNA being released into the cytosol to be translated as into an endogenous antigen, which is subsequently processed and presented to the MHC class I molecules to activate $T$ cells.

\section{CONCLUSION}

We have successfully transfected antigen presenting cells via screening of different endosomal escape peptides. The mRNA polyplexes post-modified with GALA, PPx-GALA, showed high mRNA translation in dendritic cells and macrophages. PPx-GALA exhibit sialic acid ended glycan cellular uptake and are capable to help mRNA endosomal escape. This delivery system achieved superior OVA mRNA antigen transfection efficiencies and high levels of antigen specific $\mathrm{T}$ cell responses, along with the strong immune-stimulatory properties. These results warrant further exploration of PPx-GALA as vaccine platform for the development of personalized vaccines for cancer immunotherapy.

\section{EXPERIMENTAL PROCEDURES}

Materials. All chemicals were purchased in the highest purity and used without further purification. Carbonic acid 2dimethylamino-ethyl ester 1-methyl-2-(2-methacryloylamino)ethyl ester (HPMA-DMAE), ${ }^{80} \mathrm{~N}$-[2-(2-pyridyldithio)]ethyl methacrylamide(PDTEMA), ${ }^{81,82}$ and 2-azidoethylmethyacrylamide (AzEMAm) ${ }^{24}$ were synthesized as previously reported. Lipofectamine 2000 was obtained from Thermo Fisher Scientific (Etten-Leur, The Netherlands). The EGFP-mRNA Cy5-EGFP-mRNA and Cy5-luc_mRNA (5-methoxyuridine) were purchased from Tebu-bio (TRiLink biotechnologies, San Diego, CA). LEDE-azide ${ }^{29-31}$ was a gift from Dr. Jan Wouter Drijfhout (Faculty of Medicine, Leiden University). GALAazide and Melittin-azide was provided by ChinaPeptides Co., Ltd. (Shanghai, China). Maackia amurensis agglutinin, OptiMEM, DMEM medium and heat inactivated fetal bovine serum (HI-FBS) were purchased from Sigma-Aldrich (Darmstadt, Germany).

Polymer Synthesis and Characterization. p(HPMADMAE-co-PDTEMA-co-AzEMAm) (pHDPA) was synthesized as reported. ${ }^{24}$ The polymer was synthesized by radical polymerization using a monomer to initiator molar ratio (M/ I) of 50 under a nitrogen atmosphere. The feed molar ratio of HPMA-DMAE, PDTEMA, and AzEMAm was 70/20/10. In brief, $200 \mathrm{mg}$ (0.77 mmol) HPMA-DMAE, $56.7 \mathrm{mg}$ (0.22 mmol) PDTEMA, $17 \mathrm{mg}$ (0.11 mmol) AzEMAm, and $3.6 \mathrm{mg}$ $(0.022 \mathrm{mmol})$ AIBN were dissolved in dry DMSO $(1 \mathrm{~mL})$ in flasks sealed with rubber septa and subjected to three vacuum$\mathrm{N}_{2}$ cycles. The polymerization was carried at $70{ }^{\circ} \mathrm{C}$ for $48 \mathrm{~h}$. Next, the polymer was precipitated in cold diethyl ether, redissolved in DMF and precipitated in cold diethyl ether. This procedure was repeated 3 times. After extensive dialysis (5 $\mathrm{kDa})$ against an ammonium acetate $\left(\mathrm{NH}_{4} \mathrm{OAc}\right)$ buffer of $\mathrm{pH}$ $5.0(10 \mathrm{mM}$, last step $2.5 \mathrm{mM})$ at $4{ }^{\circ} \mathrm{C}$, the polymer was collected after freeze-drying. The yield of the polymer was $40 \%$.

The molecular weights and polydisperisity $\left(M_{\mathrm{w}} / M_{\mathrm{n}}\right)$ of pHDPA were determined by size exclusion chromatography (SEC) analysis using a Viscotek-GPCmax (Viscotek, Oss, The Netherlands) light scattering $\left(\lambda=670 \mathrm{~nm}\right.$, right $\left(90^{\circ}\right)$ and low $\left(7^{\circ}\right)$ angle $) /$ viscosimetric detection system, using Ultrahydrogel $20007.8 \times 300 \mathrm{~mm}$ columns in series with a Ultrahydrogel $6.0 \times 40 \mathrm{~mm}$ guard column and $0.3 \mathrm{M} \mathrm{NaAc} \mathrm{pH}$ 4.4, $30 \%$ acetonitrile as eluent. ${ }^{83}$ The flow rate was $0.6 \mathrm{~mL} /$ $\mathrm{min}$ and the run time was $60 \mathrm{~min}$. A PolyCALTM PEO standard $\left(M_{n}=24 \mathrm{kDa}\right.$, PDI $=1.01$, Malvern $)$ was used for calibration. The copolymer composition was determined by ${ }^{1} \mathrm{H}$ NMR analysis (polymer dissolved in $\mathrm{D}_{2} \mathrm{O}$ ) and performed with a Gemini $400 \mathrm{MHz}$ spectrometer (Varian Associates Inc., NMR Instruments, Palo Alto, CA). The ratio HPMA-DMAE/ PDTEMA/AzEMAm was determined by comparison of the integrals at $\delta 4.3 \mathrm{ppm}$ (bs, $\underline{\mathrm{OH}}_{2} \mathrm{CH}_{2}, \mathrm{HPMA}-\mathrm{DMAE}$ ), $\delta 7.69$ ppm (bs, pyridyl group proton, PDTEMA) and $\delta 3.14-3.51$ ppm (m, $\underline{\mathrm{CH}}_{2} \underline{\mathrm{CH}}_{2} \mathrm{~N}_{3}$, AzEMAm).

Peptide Conjugate Synthesis. The BCN-PEG $6000^{-}$ peptides were synthesized as described in Figure S1B. Briefly, for the synthesis of BCN-PEG $6000-$ GALA, $20.9 \mathrm{mg}$ of BCN$\mathrm{PEG}_{6000}-\mathrm{BCN}(6510 \mathrm{~g} / \mathrm{mol}, 3.2 \mu \mathrm{mol})$ was dissolved in $1 \mathrm{~mL}$ dry DMSO, followed by the addition $10.0 \mathrm{mg}$ of GALA-azide (3115 $\mathrm{g} / \mathrm{mol}, 3.2 \mu \mathrm{mol}$ ) and the obtained solution was subsequently stirred for $16 \mathrm{~h}$ at room temperature. Next, 10 $\mathrm{mL}$ water was added, followed by freeze-drying. Subsequently, the product was redissolved in $2.5 \mathrm{~mL}$ nuclease-free water and purified with PD 10 column chromatography to remove unreacted peptide using nuclease-free water as eluent and freeze-dried. The product was obtained at a yield of $80 \%$. It should be noted that the applied procedure resulted in the formation of a statistical mixture of BCN-PEG-GALA, GALAPEG-GALA and unreacted BCN-PEG-BCN. The BCN-

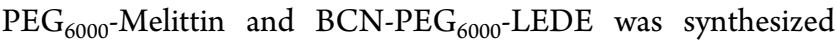
in a similar way.

Preparation and Characterization of Peptide Functionalized mRNA Polyplexes. The preparation of RNA polyplexes consisted of 3 consecutive steps: complexation, post-PEG-peptide modification, and cross-linking (Figure 1A). Briefly, complexation was achieved by mixing four volumes of polymer and one volume of nucleic acid in $10 \mathrm{mM}$ HEPES buffer, $\mathrm{pH} 7.4$, at an $\mathrm{N} / \mathrm{P}$ ratio of 4 . For control polyplexes modified with PEG, BCN-PEG ${ }_{5000}-\mathrm{COOH}^{24}$ was added to preformed mRNA polyplexes a $\mathrm{BCN} / \mathrm{N}_{3}$ mole of 0.6 . The peptide modification process was performed by mixing $\mathrm{BCN}$ $\mathrm{PEG}_{6000}$-peptide (synthesis described in Results and Discussion) at either a low (30\%) or high $(60 \%)$ molar ratio to $\mathrm{BNC} / \mathrm{N}_{3}$ in HEPES buffer $\mathrm{pH} 7.4$ to react for $2 \mathrm{~h}$ at room temperature. For the low amount of peptide modification, another $30 \%$ equivalent of $\mathrm{BCN}_{-} \mathrm{PEG}_{5000^{-}} \mathrm{COOH}$ was first mixed together $\mathrm{BCN}_{-} \mathrm{PEG}_{6000}$-peptide before addition to the mRNA polyplex dispersion. Next, surface modified mRNA polyplexes were cross-linked by addition of dithiothreitol (DTT) corresponding with a half molar equivalent to PDS 
groups of the polymer used in particle formation and subsequent incubation for $1 \mathrm{~h}$ at room temperature. After adding 5\% sucrose as cryoprotectant, the polyplexes were freeze-dried and stored at $4{ }^{\circ} \mathrm{C}$. Unless indicated otherwise, the polyplexes were prepared with a final RNA concentration of $100 \mu \mathrm{g} / \mathrm{mL}$. The mRNA polyplex dry powder was resuspended in RNAase-free water $30 \mathrm{~min}$ before addition to the cells.

The size of the polyplexes was measured with DLS using an ALV CGS-3 system (Malvern Instruments, Malvern, UK) equipped with a JDS Uniphase $22 \mathrm{~mW} \mathrm{He}-\mathrm{Ne}$ laser operating at $632.8 \mathrm{~nm}$, an optical fiber-based detector, a digital LV/LSE5003 correlator with temperature controller set at $25{ }^{\circ} \mathrm{C}$. The zeta-potential $(\zeta)$ of the polyplexes was measured using a Malvern Zetasizer Nano-Z (Malvern, UK) with universal ZEN 1002 "dip" cells and DTS (Nano) software (version 4.20) at $25{ }^{\circ} \mathrm{C}$. Polyplex measurements were performed in $10 \mathrm{mM}$ HEPES pH 7.4 and with an RNA concentration of $15 \mu \mathrm{g} / \mathrm{mL}$.

The size distribution of the polyplexes was also determined by nanoparticle tracking analysis (NTA) using a NanoSight LM 10SH (NanoSight, Amesbury, United Kingdom), equipped with a sample chamber with a $532 \mathrm{~nm}$ Laser. Typically, RNA polyplexes were diluted with PBS to a concentration of $0.5 \mu \mathrm{g} / \mathrm{mL}$ and measured for $120 \mathrm{~s}$ with manual shutter and gain adjustments. The captured videos were analyzed by the NTA 2.0 image analysis software.

Transfection of DCs. Immortalized DC2.4 cells were used to test protein expression activity of the peptide modified mRNA polyplexes. Briefly, DC2.4 cells were seeded into a 96well plate at a seeding density of $3.0 \times 10^{4}$ cells/well, and cell culture was done in $100 \mu \mathrm{L}$ complete culture medium for $24 \mathrm{~h}$ at $37{ }^{\circ} \mathrm{C}$. Prior to transfections, the medium on the cells was refreshed with either $100 \mu \mathrm{L}$ OPTI-MEM or full medium and incubated with EGFP mRNA polyplexes prepared as described in Results and Discussion for $4 \mathrm{~h}$ at $37{ }^{\circ} \mathrm{C}$, and then another $100 \mu \mathrm{L}$ full medium was added without removing polyplexes. After incubation for $20 \mathrm{~h}$ at $37{ }^{\circ} \mathrm{C}$ in a $\mathrm{CO}_{2}$ incubator, EGFP expression was visualized using Keyence BZ-9000 Microscope (Keyence, Osaka, Japan). Flow cytometry was performed to measure the percentage of GFP-positive cells compared to nontransfected cells as control using a BD FACS Canto II flow cytometer (Becton Dickinson, BD, Franklin Lakes, NJ, USA). The same procedure was also applied to determine EGFP expression in D1 dendritic cells, RAW 246.7 macrophages, and HEK293T human embryonic kidney cells. Lipofectamine 2000 (Lipo) was used as positive control (Lipo/mRNA were prepared at volume/weight ratio of $1.5 / 1)$. Unless specified cells were incubated with mRNA at dose of $250 \mathrm{ng}$ per well.

In Vitro Cytotoxicity. To determine possible cytotoxic effects of the polyplexes, the Alamar Blue cell viability assay (Invitrogen, Karlsruhe, Germany) was performed essentially as described by the manufacturer. In short, $20 \mathrm{~h}$ after transfection, the cell medium was replaced with culture medium containing Alamar Blue $(50 \mathrm{nM})$ and the cells were cultured for another 4 h. Next, $80 \mu \mathrm{L}$ of medium from each well was transferred into a flat-bottom 96-well plate to measure the light absorbance. The relative cell metabolic activity was calculated by normalizing the absorbance at $570 \mathrm{~nm}$ (reference wavelength of $630 \mathrm{~nm}$ ) with the absorbance of PBS-treated cells.

The capability of PPx-GALA to interfere with cell membrane integrity was analyzed with the CytoTox-ONE kit, which determines the lactate dehydrogenase $(\mathrm{LDH})$ release from cells after exposure to the different polyplex formulations. The assay was performed using a 96-well plate, in which 10,000 D1 cells were plated $24 \mathrm{~h}$ before the treatment. Before sample addition, the culture medium was replaced with OPTI-MEM. Next, polyplex dispersions containing 62.5, 125, 250, and 500 ng of mRNA/well were added. After $4 \mathrm{~h}$ incubation at $37{ }^{\circ} \mathrm{C}$, the supernatant was collected, $\mathrm{LDH}$ activity was determined according to the manufacturer's protocol. For the positive control, cells were $100 \%$ lysed with $1 \%$ Triton X-100.

In Vitro DCs Cellular Uptake Studies of GALAModified Polyplexes (PPX-GALA). To determine the route of cellular internalization of the PPx-GALA, D1 cells were seeded at a density of $3.0 \times 10^{4}$ cells/well in a 96-well plate or in 96-well $\mu$ Clear black plates and incubated for $24 \mathrm{~h}$ at $37^{\circ} \mathrm{C}$. The cells were then incubated with Cy5-labeled luc_mRNA loaded in PPx-GALA as described in Results and Discussion at dose of $250 \mathrm{ng}$ of mRNA/well for 1, 6, 12, and $24 \mathrm{~h}$. For inhibition studies, cells were pretreated with $1 \mu \mathrm{g} / \mathrm{mL}$ lipopolysaccharide (LPS, Invitrogen) for $15 \mathrm{~h}, 10 \mu \mathrm{M}$ Maackia amurensis agglutinin for $30 \mathrm{~min}$ (MAM, sialic acid binding lectin, Sigma), $10 \mu \mathrm{M}$ cytochalasin D (Cyto-D, phagocytosis inhibitor, Sigma) for $3 \mathrm{~h}, 15 \mu \mathrm{M}$ chlorpromazine (CPZ, clathrin-mediated endocytosis inhibitor, Sigma) for $1 \mathrm{~h}$ or different concentrations of free GALA peptide $(1-150 \mu \mathrm{M})$ for $15 \mathrm{~min}$ in full medium prior to addition of PPX-GALA to the cells. The cells were then incubated for $1 \mathrm{~h}$ (inhibitor present during transfection) at $37{ }^{\circ} \mathrm{C}$ before they were washed with ice-cold FACS buffer (1\% BSA in PBS) and applied to determine particle uptake using a BD FACSCanto II flow cytometer and high content confocal fluorescent microscope Yokogawa Cell Voyager CV7000s (Yokogawa Electric Corporation, Tokyo, Japan). For binding assay of PPxGALA, cells were first incubated on ice for $1 \mathrm{~h}$ and then incubated together with PPx-GALA for another $1 \mathrm{~h}$ on ice before taking confocal images. For colocalization studies, cells were cotransfected with PPx-GALA and $200 \mu \mathrm{g} / \mathrm{mL}$ rhodamine-labeled dextran (70,000 Da, ThermoFisher) or $150 \mu \mathrm{g} /$ $\mathrm{mL}$ cell impermeable dye Calcein (Sigma, The Netherlands) for $3 \mathrm{~h}$ at $37^{\circ} \mathrm{C}$. To study the subcellular distribution, after $3 \mathrm{~h}$ coincubation with PPx-GALA, the cells were incubated with $100 \mathrm{nM}$ lysotracker green (Invitrogen, The Netherlands) for $30 \mathrm{~min}$ before confocal imaging.

In Vitro DCs Maturation and Antigen Presentation. D1 cells were seeded in 96-well plates at a density of 25,000 cells/well in $100 \mu \mathrm{L}$ complete medium and allowed to adhere overnight. Polyplexes or lipoplexes were added at $0.25 \mu \mathrm{g}$ mRNA/well in $100 \mu \mathrm{L}$ serum-free media. Control cells were treated with $0.1 \mathrm{mM}$ SIINFEKL peptide (in vitrogen, The Netherlands). After incubation for 6, 12, and $24 \mathrm{~h}$ at $37^{\circ} \mathrm{C}$, the cells were washed with medium, new fresh complete medium was added and incubated for overnight at $37^{\circ} \mathrm{C}$. Next, 100,000 B3Z cells/well in $100 \mu \mathrm{L}$ complete medium were added and incubated for $24 \mathrm{~h}$ at $37{ }^{\circ} \mathrm{C}$. The medium was then replaced with $100 \mu \mathrm{L} /$ well lysis buffer containing $0.1 \mathrm{mM} \mathrm{2-}$ mercaptoethanol, $9 \mathrm{mM} \mathrm{MgCl}_{2}, 0.1 \%$ Triton X-100, and $0.15 \mathrm{mM}$ chlorophenol red $\beta$-D-galactopyranoside (CPRG) in DPBS. After $2 \mathrm{~h}$ incubation at $37{ }^{\circ} \mathrm{C}$, absorbance measurements were recorded at $570 \mathrm{~nm}$. To measure the maturation level of the D1 cells, after incubation of the cells with the different formulations for $24 \mathrm{~h}$ at $37^{\circ} \mathrm{C}$, the cells were washed with FACS buffer and subsequently stained with anti-CD40FITC and anti-CD86-PE antibodies $(2 \mu \mathrm{g} / \mathrm{mL}, 50 \mu \mathrm{L} /$ well, eBioscience, U.S.) for $30 \mathrm{~min}$ on ice. The D1 cells were subsequently analyzed by flow cytometry after 2 washing steps with FACS buffer. 
Statistical Analysis. Two-tailed Student's $t$ test was applied for comparison between experimental groups. $P<$ 0.05 was considered statistically significant.

\section{ASSOCIATED CONTENT}

\section{S Supporting Information}

The Supporting Information is available free of charge on the ACS Publications website at DOI: 10.1021/acs.bioconjchem. 8 b00524.

NMR spectra, Nanoparticle tracking analysis (NTA), Cell viability, Flow cytometry histograms, and representative confocal microscope images (PDF)

\section{AUTHOR INFORMATION}

\section{Corresponding Author}

*E-mail: E.Mastrobattista@uu.nl. Tel: +31 (0)62 2736567.

\section{ORCID}

Wim E. Hennink: 0000-0002-5750-714X

Enrico Mastrobattista: 0000-0002-6745-2015

Notes

The authors declare no competing financial interest.

\section{ACKNOWLEDGMENTS}

Bo Lou was funded by China scholarship Council (CSC). We thank Dr. Jan Wouter Drijfhout from Leiden University for providing the LEDE peptide.

\section{REFERENCES}

(1) Pollard, C., De Koker, S., Saelens, X., Vanham, G., and Grooten, J. (2013) Challenges and advances towards the rational design of mRNA vaccines. Trends Mol. Med. 19 (12), 705-713.

(2) Neelapu, S. S., Tummala, S., Kebriaei, P., Wierda, W., Gutierrez, C., Locke, F. L., Komanduri, K. V., Lin, Y., Jain, N., Daver, N., et al. (2017) Chimeric antigen receptor T-cell therapy - assessment and management of toxicities. Nat. Rev. Clin. Oncol. 15 (1), 47-62.

(3) Roybal, K. T. (2018) Refining cell therapy. Science (Washington, DC, U. S.) 359 (6380), 1112-1113.

(4) Palucka, A. K., and Coussens, L. M. (2016) The Basis of Oncoimmunology. Cell 164 (6), 1233-1247.

(5) Melief, C. J. M., van Hall, T., Arens, R., Ossendorp, F., and van der Burg, S. H. (2015) Therapeutic cancer vaccines. J. Clin. Invest. 125 (9), 3401-3412.

(6) Pascolo, S. Vaccination with Messenger RNA (mRNA); SpringerL Berlin, Heidelberg, pp 221-235.

(7) De Beuckelaer, A., Grooten, J., and De Koker, S. (2017) Type I Interferons Modulate CD8+ T Cell Immunity to mRNA Vaccines. Trends Mol. Med. 23 (3), 216-226.

(8) Yin, H., Kanasty, R. L., Eltoukhy, A. A., Vegas, A. J., Dorkin, J. R., and Anderson, D. G. (2014) Non-viral vectors for gene-based therapy. Nat. Rev. Genet. 15 (8), 541-555.

(9) Kauffman, K. J., Webber, M. J., and Anderson, D. G. (2016) Materials for non-viral intracellular delivery of messenger RNA therapeutics. J. Controlled Release 240, 227-234.

(10) Fenton, O. S., Kauffman, K. J., McClellan, R. L., Appel, E. A., Dorkin, J. R., Tibbitt, M. W., Heartlein, M. W., DeRosa, F., Langer, R., and Anderson, D. G. (2016) Bioinspired Alkenyl Amino Alcohol Ionizable Lipid Materials for Highly Potent In Vivo mRNA Delivery. Adv. Mater. 28 (15), 2939-2943.

(11) Oberli, M. A., Reichmuth, A. M., Dorkin, J. R., Mitchell, M. J., Fenton, O. S., Jaklenec, A., Anderson, D. G., Langer, R., and Blankschtein, D. (2017) Lipid Nanoparticle Assisted mRNA Delivery for Potent Cancer Immunotherapy. Nano Lett. 17 (3), 1326-1335.

(12) Hirschberger, K., Jarzebinska, A., Kessel, E., Kretzschmann, V., Aneja, M. K., Dohmen, C., Herrmann-Janson, A., Wagner, E., Plank, C., and Rudolph, C. (2018) Exploring Cytotoxic mRNAs as a Novel
Class of Anti-cancer Biotherapeutics. Mol. Ther.-Methods Clin. Dev. 8, $141-151$.

(13) Persano, S., Guevara, M. L., Li, Z., Mai, J., Ferrari, M., Pompa, P. P., and Shen, H. (2017) Lipopolyplex potentiates anti-tumor immunity of mRNA-based vaccination. Biomaterials 125, 81-89.

(14) Kranz, L. M., Diken, M., Haas, H., Kreiter, S., Loquai, C., Reuter, K. C., Meng, M., Fritz, D., Vascotto, F., Hefesha, H., et al. (2016) Systemic RNA delivery to dendritic cells exploits antiviral defence for cancer immunotherapy. Nature 534 (7607), 396-401.

(15) Verbeke, R., Lentacker, I., Wayteck, L., Breckpot, K., Van Bockstal, M., Descamps, B., Vanhove, C., De Smedt, S. C., and Dewitte, H. (2017) Co-delivery of nucleoside-modified mRNA and TLR agonists for cancer immunotherapy: Restoring the immunogenicity of immunosilent mRNA. J. Controlled Release 266, 287-300.

(16) Lachelt, U., and Wagner, E. (2015) Nucleic Acid Therapeutics Using Polyplexes: A Journey of 50 Years (and Beyond). Chem. Rev. 115 (19), 11043-11078.

(17) Uchida, S., Kinoh, H., Ishii, T., Matsui, A., Tockary, T. A., Takeda, K. M., Uchida, H., Osada, K., Itaka, K., and Kataoka, K. (2016) Systemic delivery of messenger RNA for the treatment of pancreatic cancer using polyplex nanomicelles with a cholesterol moiety. Biomaterials 82, 221-228.

(18) Uchida, S., Itaka, K., Uchida, H., Hayakawa, K., Ogata, T., Ishii, T., Fukushima, S., Osada, K., and Kataoka, K. (2013) In vivo messenger RNA introduction into the central nervous system using polyplex nanomicelle. PLoS One 8 (2), e56220.

(19) Bettinger, T., Carlisle, R. C., Read, M. L., Ogris, M., and Seymour, L. W. (2001) Peptide-mediated RNA delivery: a novel approach for enhanced transfection of primary and post-mitotic cells. Nucleic Acids Res. 29 (18), 3882-3891.

(20) McKinlay, C. J., Vargas, J. R., Blake, T. R., Hardy, J. W., Kanada, M., Contag, C. H., Wender, P. A., and Waymouth, R. M. (2017) Charge-altering releasable transporters (CARTs) for the delivery and release of mRNA in living animals. Proc. Natl. Acad. Sci. U. S. A. 114 (4), E448-E456.

(21) Zheng, N., Yin, L., Song, Z., Ma, L., Tang, H., Gabrielson, N. P., $\mathrm{Lu}, \mathrm{H}$., and Cheng, J. (2014) Maximizing gene delivery efficiencies of cationic helical polypeptides via balanced membrane penetration and cellular targeting. Biomaterials 35 (4), 1302-1314.

(22) Su, X., Fricke, J., Kavanagh, D. G., and Irvine, D. J. (2011) In vitro and in vivo mRNA delivery using lipid-enveloped $\mathrm{pH}$-responsive polymer nanoparticles. Mol. Pharmaceutics 8 (3), 774-787.

(23) Cheng, C., Convertine, A. J., Stayton, P. S., and Bryers, J. D. (2012) Multifunctional triblock copolymers for intracellular messenger RNA delivery. Biomaterials 33 (28), 6868-6876.

(24) Lou, B., De Beuckelaer, A., Dakwar, G. R., Remaut, K., Grooten, J., Braeckmans, K., De Geest, B. G., Mastrobattista, E., De Koker, S., and Hennink, W. E. (2018) Post-PEGylated and crosslinked polymeric ssRNA nanocomplexes as adjuvants targeting lymph nodes with increased cytolytic $\mathrm{T}$ cell inducing properties. $J$. Controlled Release 284, 73-83.

(25) Meyer, M., Philipp, A., Oskuee, R., Schmidt, C., and Wagner, E. (2008) Breathing life into polycations: Functionalization with $\mathrm{pH}-$ responsive endosomolytic peptides and polyethylene glycol enables siRNA delivery. J. Am. Chem. Soc. 130 (11), 3272-3273.

(26) Huang, C., Jin, H., Qian, Y., Qi, S., Luo, H., Luo, Q., and Zhang, Z. (2013) Hybrid melittin cytolytic peptide-driven ultrasmall lipid nanoparticles block melanoma growth in vivo. ACS Nano 7 (7), 5791-5800.

(27) Hatakeyama, H., Ito, E., Akita, H., Oishi, M., Nagasaki, Y., Futaki, S., and Harashima, H. (2009) A pH-sensitive fusogenic peptide facilitates endosomal escape and greatly enhances the gene silencing of siRNA-containing nanoparticles in vitro and in vivo. J. Controlled Release 139 (2), 127-132.

(28) Li, W., Nicol, F., and Szoka, F. C. (2004) GALA: a designed synthetic $\mathrm{pH}$-responsive amphipathic peptide with applications in drug and gene delivery. Adv. Drug Delivery Rev. 56 (7), 967-985.

(29) Nell, M. J., Tjabringa, G. S., Wafelman, A. R., Verrijk, R., Hiemstra, P. S., Drijfhout, J. W., and Grote, J. J. (2006) Development 
of novel LL-37 derived antimicrobial peptides with LPS and LTA neutralizing and antimicrobial activities for therapeutic application. Peptides 27 (4), 649-660.

(30) de Breij, A., Riool, M., Kwakman, P. H. S., de Boer, L., Cordfunke, R. A., Drijfhout, J. W., Cohen, O., Emanuel, N., Zaat, S. A. J., Nibbering, P. H., et al. (2016) Prevention of Staphylococcus aureus biomaterial-associated infections using a polymer-lipid coating containing the antimicrobial peptide OP-145. J. Controlled Release $222,1-8$.

(31) Göblyös, A., Schimmel, K. J. M., Valentijn, A. R. P. M., Fathers, L. M., Cordfunke, R. A., Chan, H. L., Oostendorp, J., Nibbering, P. H., Drijfhout, J. W., Hiemstra, P. S., et al. (2013) Development of a Nose Cream Containing the Synthetic Antimicrobial Peptide P60.4Ac for Eradication of Methicillin-Resistant Staphylococcus aureus Carriage. J. Pharm. Sci. 102 (10), 3539-3544.

(32) Dumortier, H., van Mierlo, G. J. D., Egan, D., van Ewijk, W., Toes, R. E. M., Offringa, R., and Melief, C. J. M. (2005) Antigen presentation by an immature myeloid dendritic cell line does not cause CTL deletion in vivo, but generates CD8+ central memory-like $\mathrm{T}$ cells that can be rescued for full effector function. J. Immunol. 175 (2), 855-863.

(33) Winzler, C., Rovere, P., Rescigno, M., Granucci, F., Penna, G., Adorini, L., Zimmermann, V. S., Davoust, J., and Ricciardi-Castagnoli, P. (1997) Maturation stages of mouse dendritic cells in growth factordependent long-term cultures. J. Exp. Med. 185 (2), 317-328.

(34) Zou, S., Scarfo, K., Nantz, M. H., and Hecker, J. G. (2010) Lipid-mediated delivery of RNA is more efficient than delivery of DNA in non-dividing cells. Int. J. Pharm. 389 (1-2), 232-243.

(35) Phua, K. K. L., Leong, K. W., and Nair, S. K. (2013) Transfection efficiency and transgene expression kinetics of mRNA delivered in naked and nanoparticle format. J. Controlled Release 166 (3), 227-233.

(36) Chang, T. Z., Stadmiller, S. S., Staskevicius, E., and Champion, J. A. (2016) Effects of ovalbumin protein nanoparticle vaccine size and coating on dendritic cell processing. Biomater. Sci. 5, 223.

(37) Lebre, F., Hearnden, C. H., and Lavelle, E. C. (2016) Modulation of Immune Responses by Particulate Materials. Adv. Mater. 28, 5525-5541.

(38) Kumar, S., Anselmo, A. C., Banerjee, A., Zakrewsky, M., and Mitragotri, S. (2015) Shape and size-dependent immune response to antigen-carrying nanoparticles. J. Controlled Release 220, 141-148.

(39) Zaki, N. M., and Tirelli, N. (2010) Gateways for the intracellular access of nanocarriers: a review of receptor-mediated endocytosis mechanisms and of strategies in receptor targeting. Expert Opin. Drug Delivery 7 (8), 895-913.

(40) Schach, D. K., Rock, W., Franz, J., Bonn, M., Parekh, S. H., and Weidner, T. (2015) Reversible Activation of a Cell-Penetrating Peptide in a Membrane Environment. J. Am. Chem. Soc. 137 (38), 12199-12202.

(41) Kusumoto, K., Akita, H., Ishitsuka, T., Matsumoto, Y., Nomoto, T., Furukawa, R., El-Sayed, A., Hatakeyama, H., Kajimoto, K., Yamada, Y., et al. (2013) Lipid envelope-type nanoparticle incorporating a multifunctional peptide for systemic siRNA delivery to the pulmonary endothelium. ACS Nano 7 (9), 7534-7541.

(42) Santiwarangkool, S., Akita, H., Nakatani, T., Kusumoto, K., Kimura, H., Suzuki, M., Nishimura, M., Sato, Y., and Harashima, H. (2017) PEGylation of the GALA Peptide Enhances the LungTargeting Activity of Nanocarriers That Contain Encapsulated siRNA. J. Pharm. Sci. 106 (9), 2420-2427.

(43) Crespo, H. J., Lau, J. T. Y., and Videira, P. A. (2013) Dendritic cells: A spot on sialic acid. Front. Immunol. 4 (DEC), 1-15.

(44) Stamatos, N. M., Carubelli, I., van de Vlekkert, D., Bonten, E. J., Papini, N., Feng, C., Venerando, B., D’Azzo, A., Cross, A. S., Wang, L.-X., et al. (2010) LPS-induced cytokine production in human dendritic cells is regulated by sialidase activity. J. Leukocyte Biol. 88 (6), 1227-1239.

(45) Knibbs, R. N., Goldstein, I. J., Ratcliffe, R. M., and Shibuya, N. (1991) Characterization of the carbohydrate binding specificity of the leukoagglutinating lectin from Maackia amurensis: Comparison with other sialic acid-specific lectins. J. Biol. Chem. 266 (1), 83-88.

(46) Videira, P. A., Amado, I. F., Crespo, H. J., Algueró, M. C., Dall'Olio, F., Cabral, M. G., and Trindade, H. (2008) Surface $\alpha 2-3-$ and $\alpha 2-6$-sialylation of human monocytes and derived dendritic cells and its influence on endocytosis. Glycoconjugate J. 25 (3), 259-268.

(47) Cabral, M. G., Silva, Z., Ligeiro, D., Seixas, E., Crespo, H., Carrascal, M. A., Silva, M., Piteira, A. R., Paixão, P., Lau, J. T., et al. (2013) The phagocytic capacity and immunological potency of human dendritic cells is improved by $\alpha 2,6$-sialic acid deficiency. Immunology 138 (3), 235-245.

(48) Sallusto, F., Cella, M., Danieli, C., and Lanzavecchia, A. (1995) Dendritic cells use macropinocytosis and the mannose receptor to concentrate macromolecules in the major histocompatibility complex class II compartment: downregulation by cytokines and bacterial products. J. Exp. Med. 182 (2), 389-400.

(49) Platt, C. D., Ma, J. K., Chalouni, C., Ebersold, M., Bou-Reslan, H., Carano, R. A. D., Mellman, I., and Delamarre, L. (2010) Mature dendritic cells use endocytic receptors to capture and present antigens. Proc. Natl. Acad. Sci. U. S. A. 107 (9), 4287-4292.

(50) Commisso, C., Flinn, R. J., and Bar-Sagi, D. (2014) Determining the macropinocytic index of cells through a quantitative image-based assay. Nat. Protoc. 9 (1), 182-192.

(51) Lukacs, G. L., Haggie, P., Seksek, O., Lechardeur, D., Freedman, N., and Verkman, A. S. (2000) Size-dependent DNA mobility in cytoplasm and nucleus. J. Biol. Chem. 275 (3), 1625-1629.

(52) Jones, R. A., Cheung, C. Y., Black, F. E., Zia, J. K., Stayton, P. S., Hoffman, A. S., and Wilson, M. R. (2003) Poly(2-alkylacrylic acid) polymers deliver molecules to the cytosol by $\mathrm{pH}$-sensitive disruption of endosomal vesicles. Biochem. J. 372, 65-75.

(53) Adler, J., and Parmryd, I. (2010) Quantifying colocalization by correlation: The pearson correlation coefficient is superior to the Mander's overlap coefficient. Cytometry, Part A 77 (8), 733-742.

(54) Yapici, N. B., Bi, Y., Li, P., Chen, X., Yan, X., Mandalapu, S. R., Faucett, M., Jockusch, S., Ju, J., Gibson, K. M., et al. (2015) Highly stable and sensitive fluorescent probes (LysoProbes) for lysosomal labeling and tracking. Sci. Rep. 5 (1), 8576.

(55) Karttunen, J., Sanderson, S., and Shastri, N. (1992) Detection of rare antigen-presenting cells by the lacZ $\mathrm{T}$-cell activation assay suggests an expression cloning strategy for T-cell antigens. Proc. Natl. Acad. Sci. U. S. A. 89 (13), 6020-6024.

(56) Xue, G., Cheng, Y., Ran, F., Li, X., Huang, T., Yang, Y., and Zhang, Y. (2013) SLC gene-modified dendritic cells mediate T celldependent anti-gastric cancer immune responses in vitro. Oncol. Rep. 29 (2), 595-604.

(57) Kakudo, T., Chaki, S., Futaki, S., Nakase, I., Akaji, K., Kawakami, T., Maruyama, K., Kamiya, H., and Harashima, H. (2004) Transferrin-Modified Liposomes Equipped with a pH-Sensitive Fusogenic Peptide: An Artificial Viral-like Delivery System. Biochemistry 43 (19), 5618-5628.

(58) Zheng, N., Yin, L., Song, Z., Ma, L., Tang, H., Gabrielson, N. P., $\mathrm{Lu}, \mathrm{H}$., and Cheng, J. (2014) Maximizing gene delivery efficiencies of cationic helical polypeptides via balanced membrane penetration and cellular targeting. Biomaterials 35 (4), 1302-1314.

(59) Irvine, A. S., Trinder, P. K. E., Laughton, D. L., Ketteringham, H., McDermott, R. H., Reid, S. C. H., Haines, A. M. R., Amir, A., Husain, R., Doshi, R., et al. (2000) Efficient nonviral transfection of dendritic cells and their use for in vivo immunization. Nat. Biotechnol. 18 (12), 1273-1278.

(60) Nakase, I., and Futaki, S. (2015) Combined treatment with a $\mathrm{pH}$-sensitive fusogenic peptide and cationic lipids achieves enhanced cytosolic delivery of exosomes. Sci. Rep. 5 (1), 10112.

(61) Nouri, F. S., Wang, X., Dorrani, M., Karjoo, Z., and Hatefi, A. (2013) A recombinant biopolymeric platform for reliable evaluation of the activity of $\mathrm{pH}$-responsive amphiphile fusogenic peptides. Biomacromolecules 14 (6), 2033-2040.

(62) Haensler, J., and Szoka, F. C. (1993) Polyamidoamine cascade polymers mediate efficient transfection of cells in culture. Bioconjugate Chem. 4 (5), 372-379. 
(63) Youn, H., and Chung, J.-K. (2015) Modified mRNA as an alternative to plasmid DNA (pDNA) for transcript replacement and vaccination therapy. Expert Opin. Biol. Ther. 15 (9), 1337-1348.

(64) Akita, H., Kogure, K., Moriguchi, R., Nakamura, Y., Higashi, T., Nakamura, T., Serada, S., Fujimoto, M., Naka, T., Futaki, S., et al. (2011) Nanoparticles for ex vivo siRNA delivery to dendritic cells for cancer vaccines: Programmed endosomal escape and dissociation. J. Controlled Release 149 (1), 58-64.

(65) Brülisauer, L., Gauthier, M. A., and Leroux, J. C. (2014) Disulfide-containing parenteral delivery systems and their redoxbiological fate. J. Controlled Release 195, 147-154.

(66) Ramos, I., and Fernandez-Sesma, A. (2012) Cell receptors for influenza A viruses and the innate immune response. Front. Microbiol. 3, 117.

(67) Passaniti, A., and Hart, W. (1988) Cell Surface Sialylation and Tumor Metastasis. J. Biochem. 263 (16), 725-729.

(68) Park, J.-J., and Lee, M. (2013) Increasing the $\alpha 2$, 6 sialylation of glycoproteins may contribute to metastatic spread and therapeutic resistance in colorectal cancer. Gut Liver 7 (6), 629-641.

(69) Schauer, R. (2004) Sialic acids: fascinating sugars in higher animals and man. Zoology 107 (1), 49-64.

(70) Kubota, M., Takeuchi, K., Watanabe, S., Ohno, S., Matsuoka, R., Kohda, D., Nakakita, S.-I., Hiramatsu, H., Suzuki, Y., Nakayama, T., et al. (2016) Trisaccharide containing $\alpha 2,3$-linked sialic acid is a receptor for mumps virus. Proc. Natl. Acad. Sci. U. S. A. 113 (41), 11579-11584.

(71) Savina, A., Jancic, C., Hugues, S., Guermonprez, P., Vargas, P., Moura, I. C., Lennon-Duménil, A. M., Seabra, M. C., Raposo, G., and Amigorena, S. (2006) NOX2 Controls Phagosomal pH to Regulate Antigen Processing during Crosspresentation by Dendritic Cells. Cell 126 (1), 205-218.

(72) Peachman, K. K., Rao, M., Alving, C. R., Palmer, D. R., Sun, W., and Rothwell, S. W. (2005) Human dendritic cells and macrophages exhibit different intracellular processing pathways for soluble and liposome-encapsulated antigens. Immunobiology 210 (5), 321-333.

(73) Tran, K. K., and Shen, H. (2009) The role of phagosomal pH on the size-dependent efficiency of cross-presentation by dendritic cells. Biomaterials 30 (7), 1356-1362.

(74) Kranz, L. M., Diken, M., Haas, H., Kreiter, S., Loquai, C., Reuter, K. C., Meng, M., Fritz, D., Vascotto, F., Hefesha, H., et al. (2016) Systemic RNA delivery to dendritic cells exploits antiviral defence for cancer immunotherapy. Nature 534 (7607), 396-401.

(75) Persano, S., Guevara, M. L., Li, Z., Mai, J., Ferrari, M., Pompa, P. P., and Shen, H. (2017) Lipopolyplex potentiates anti-tumor immunity of mRNA-based vaccination. Biomaterials 125, 81-89.

(76) Lukacs, G. L., Haggie, P., Seksek, O., Lechardeur, D., Freedman, N., and Verkman, A. S. (2000) Size-dependent DNA mobility in cytoplasm and nucleus. J. Biol. Chem. 275 (3), 1625-1629.

(77) Rehman, Z. U., Hoekstra, D., and Zuhorn, I. S. (2013) Mechanism of polyplex- and lipoplex-mediated delivery of nucleic acids: Real-time visualization of transient membrane destabilization without endosomal lysis. ACS Nano 7 (5), 3767-3777.

(78) Wittrup, A., Ai, A., Liu, X., Hamar, P., Trifonova, R., Charisse, K., Manoharan, M., Kirchhausen, T., and Lieberman, J. (2015) Visualizing lipid-formulated siRNA release from endosomes and target gene knockdown. Nat. Biotechnol. 33 (8), 870-876.

(79) Kormann, M. S. D., Hasenpusch, G., Aneja, M. K., Nica, G., Flemmer, A. W., Herber-Jonat, S., Huppmann, M., Mays, L. E., Illenyi, M., Schams, A., et al. (2011) Expression of therapeutic proteins after delivery of chemically modified mRNA in mice. Nat. Biotechnol. 29 (2), 154-159.

(80) Funhoff, A. M., Van Nostrum, C. F., Janssen, A. P. C. A., Fens, M. H. A. M., Crommelin, D. J. A., and Hennink, W. E. (2004) Polymer Side-Chain Degradation as a Tool to Control the Destabilization of Polyplexes. Pharm. Res. 21 (1), 170-176.

(81) Zugates, G. T., Anderson, D. G., Little, S. R., Lawhorn, I. E. B., and Langer, R. (2006) Synthesis of poly(beta-amino ester)s with thiol-reactive side chains for DNA delivery. J. Am. Chem. Soc. 128 (39), 12726-12734.
(82) Novo, L., Van Gaal, E. V. B., Mastrobattista, E., Van Nostrum, C. F., and Hennink, W. E. (2013) Decationized crosslinked polyplexes for redox-triggered gene delivery. J. Controlled Release 169, 246-256.

(83) Jiang, X., van der Horst, A., van Steenbergen, M. J., Akeroyd, N., van Nostrum, C. F., Schoenmakers, P. J., and Hennink, W. E. (2006) Molar-mass characterization of cationic polymers for gene delivery by aqueous size-exclusion chromatography. Pharm. Res. 23 (3), 595-603. 